\title{
State Liability for Breach of Article II.3 of the 1958 New York Convention
}

\author{
Julio César Betancourt*
}

\begin{abstract}
This article examines the concept of state liability for non-compliance with the obligation to refer the parties to arbitration pursuant to Article II.3 of the 1958 New York Convention. Article II. 3 of the New York Convention obligates the courts of contracting states to safeguard the party against whom legal proceedings have been initiated in violation of a valid international arbitration agreement. The author argues that when the court of a given contracting state decides not to refer the parties to arbitration, particularly, in those cases involving the application of foreign law, and in which an error of judgment has been made (ie misapplication, misinterpretation, or lack of application of the law governing the agreement to arbitrate), the injured party should be entitled to make a claim for damages against the relevant contracting state for breach of a New York Convention right, ie the right to arbitrate.
\end{abstract}

\section{INTRODUCTION}

The 1958 Convention on the Recognition and Enforcement of Foreign Arbitral Awards (otherwise known as the 'New York Convention') ${ }^{1}$ has been described as

* Julio César Betancourt, University of Oxford, Faculty of Law. He was admitted to the practice of law in 2001. He has advised and successfully represented a large number of public and private sector clients in a variety of matters. Julio César holds a bachelor's degree in law and postgraduate degrees in the areas of damages, procedural law, international business law, constitutional law, and contract law and damages. He obtained his master's in law from University College London (UCL), specializing in alternative dispute resolution (ADR), dispute resolution and conflict management, and international arbitration. Julio César is the editor of Defining Issues in International Arbitration: Celebrating 100 Years of the Chartered Institute of Arbitrators (OUP 2016). He is also a Visiting Research Fellow at King's College London and a Junior Academic Visitor at Harris Manchester College (University of Oxford). In 2015, Julio César started pursuing doctoral studies in the field of international arbitration at the University of Salamanca and, as such, he was subsequently awarded recognized student status at the University of Oxford (Faculty of Law) so as to undertake his research. Prior to joining the University of Oxford, he was the Chartered Institute of Arbitrators' Head of Research and Academic Affairs. Email: julio-cesar.betancourt@law.ox.ac.uk

+ Research for this article was conducted at Harvard Law School. The author would like to thank Marilyn Uzuner, Faculty Assistant, for her invaluable support. The author would also like to thank Professor William W Park, Sir Bernard Rix, Claudia Pharaon, and Elina Zlatanska for their incisive comments on an earlier version of this article.

1 For a commentary on the New York Convention, see Marike Paulsson, The 1958 New York Convention in Action (Kluwer Law International 2016) 1-262; Reinmar Wolff (ed), The New York Convention: Commentary (Hart Publishing 2012) 1-613; and Herbert Kronke and others (eds), Recognition and 


\section{KEY REFERENCES}

- Convention on the Recognition and Enforcement of Foreign Arbitral Awards (1958)

- Brussels Convention on Jurisdiction and the Enforcement of judgments in Civil and Commercial Matters (1968)

- Vienna Convention on the Law of Treaties (1969)

- International Law Commission's Articles on Responsibility of States for Internationally Wrongful Acts (2001)

- Convention on Choice of Court Agreements (2005)

- Regulation (EC) No 593/2008 of the European Parliament and of the Council of 17 June 2008 on the Law Applicable to Contractual Obligations (Rome I)

- Council Regulation (EC) 44/2001 of 22 December 2000 on Jurisdiction and the Recognition and Enforcement of Judgments in Civil and Commercial Matters

- Regulation (EU) 1215/2012 of the European Parliament and of the Council of 12 December 2012 on Jurisdiction and the Recognition and Enforcement of Judgments in Civil and Commercial Matters (Recast)

- National Navigation Co v Endesa Generacion SA [2009] EWHC 196 (Comm) (01 April 2009)

- National Navigation Co v Endesa Generacion SA [2009] EWCA Civ 1397 (17 December 2009)

'the keystone on which the edifice of International Commercial Arbitration is built'. It is well established that the aim of the New York Convention is two-fold: (i) to facilitate the recognition and enforcement of international arbitration agreements; and (ii) to provide for the recognition and enforcement of foreign arbitral awards. ${ }^{3}$

Enforcement of Foreign Arbitral Awards: A Global Commentary on the New York Convention (Kluwer Law International 2010) 1-602.

2 Eric E Bergsten, in Margaret Moses, The Principles and Practice of International Commercial Arbitration (Cambridge University Press 2008) xiii. The Convention has also been described as 'one of the most successful treaties in the area of commercial law', see Kofi Annan, 'The 1958 New York Convention as a Model for Subsequent Legislative Texts on Arbitration' (1999) 15 Arbitration International 320. In addition, the Convention is said to establish 'a constitutional framework for the conduct of international commercial arbitrations around the world', Gary B Born, 'International Commercial Arbitration' (Kluwer Arbitration Blog, 12 February 2009) < kluwerarbitrationblog.com> accessed 13 July 2016.

3 The full title of the Convention, ie Convention on the Recognition and Enforcement of Foreign Arbitral Awards, 'suggests that it is concerned only with the recognition and enforcement of foreign arbitral awards. This is misleading. The Convention is also concerned with arbitration agreements', see Nigel Blackaby and others, Redfern and Hunter on International Arbitration (6th edn, OUP 2015) para 1.212. 
At the time of writing, the Convention has been ratified by over 150 contracting states. ${ }^{4}$ All contracting states-or States Parties-have something in common: they have expressed their consent to be bound by the Convention; ${ }^{5}$ subject to certain reservations. $^{6}$ Because of the legally binding nature of this multilateral-and vertical $^{7}$ - treaty, it can be said that States Parties should take 'all appropriate measures' to ensure fulfilment of their 'obligations' under it. ${ }^{8}$

Although the New York Convention calls upon 'states parties' to achieve its aim, the truth of the matter is that its implementation is left to the 'courts of contracting states' in exercise of their 'jurisdictional power'. 9 Thus, it can be argued that, when such a power results in the violation of this multilateral treaty, contracting states must be held liable for the infringement of the provisions contained therein, ${ }^{10}$ or else it can be categorically concluded that the Convention is not worth the paper it is written on.

To illustrate this point, one may take as an example Article II.3 of the Convention, which stipulates that:

The court of a Contracting State, when seized of an action in a matter in respect of which the parties have made an agreement within the meaning of this article, shall, ${ }^{11}$ at the request of one of the parties, refer the parties to

4 See United Nations Treaty Collection, Convention on the Recognition and Enforcement of Foreign Arbitral Awards < https://treaties.un.org $>$ accessed 7 December 2015.

5 See, generally, Alexandru Bolintineanu, 'Expression of Consent to Be Bound by a Treaty in the Light of the 1969 Vienna Convention’ (1974) 68 American Journal of International Law 672-86.

6 Under international law, 'A reservation is a declaration made by a state by which it purports to exclude or alter the legal effect of certain provisions of the treaty in their application to that state', see United Nations Treaty Collection, 'Glossary of Terms relating to Treaty Actions: Reservation' <https://treaties. un.org $>$ accessed 28 January 2015. Note that art I.3 of the Convention enables contracting states to make two types of reservations, ie a 'reciprocity reservation' and a 'commercial reservation'. See Hans Bagner, 'Article I' in Herbert Kronke and others (eds), Recognition and Enforcement of Foreign Arbitral Awards: A Global Commentary on the New York Convention (Kluwer Law International 2010) 20.

7 It is said that 'vertical treaties (unlike horizontal treaties) [are treaties that] create rights for private parties', and the New York Convention is the source of many different rights, including 'the right to arbitrate', see David Sloss, 'Domestic Application of Treaties' in Duncan Hollis (ed), The Oxford Guide to Treaties (Oxford University Press 2014) 376.

8 Contracting states are legally bound under the principle [of Pacta Sunt Servanda] to implement what the law prescribes', see I Lukashuk, 'The Principle Pacta Sunt Servanda and the Nature of Obligation under International Law' (1989) 83 The American Journal of International Law 513.

9 As to the notion of 'jurisdictional power', see Julio César Betancourt, 'Understanding the Authority of International Tribunals: A Reply to Professor Jan Paulsson' (2013) 4 Journal of International Dispute Settlement 227-44.

10 Under international law, 'Once a State has become party to a treaty at the international level, its international responsibility is engaged', see Treaty Section of the Office of Legal Affairs, Treaty Handbook (United Nations 2012) 3. Further, it is said that 'When a domestic court acts, it acts as an organ of the State for whose actions the State is internationally responsible', in Stephen M Schwebel, 'Anti-Suit Injuctions in International Arbitration: An Overview' in Emmanuel Gaillard (ed), Anti-Suit Injuctions in International Arbitration (Juris Publishing 2005) 10.

11 It is interesting to note that, unlike art V.1 of the New York Convention, according to which recognition and enforcement of the award 'may' be refused at the request of the party against whom it is invoked, art II.3 uses the modal verb 'shall'. Perkins writes: 'from 1370 to 1570 SHALL meant "I must, am under an obligation to" ', see Michael Perkins, 'Core Meaning of the English Modals' (1982) 18 Journal of Linguistics 264. Williams explains that although 'by the late 1990s shall had indeed been banished from a 
arbitration, unless it finds that the said agreement is null and void, inoperative or incapable of being performed. ${ }^{12}$

It has been said that 'The quoted language is so ambiguous that it raises grave doubts as to the effectiveness of Article II. ${ }^{, 13}$ However, that is a slight exaggeration. ${ }^{14}$ While there is certainly no absolute consensus among States Parties with respect to the meaning of these expressions, ie (i) null and void, (ii) inoperative, or (iii) incapable of being performed, national courts of some contracting states have made use of their interpretative tools to grapple with this terminology ${ }^{15}$ and, eventually, clarified the meaning of these expressions through case law. ${ }^{16}$

Perhaps the least controversial of the three is that of 'null and void'. ${ }^{17}$ Oftentimes, what might prove problematic is that, unlike the Convention on Choice of Court Agreements of 30 June 2005, ${ }^{18}$ for instance, Article II.3 of the New York

number of ... legal texts ... in the major international organizations such as the United Nations ... the legislative drafters ... tended to cling to tradition', in Christopher Williams, 'Legal English and the "Modal Revolution" ' in Raphael Salkie, Pierre Busuttil and Johan van der Auwera (eds), Modality in English: Theory and Description (Mouton de Gruyter 2009) 200. This observation is important because, not that long ago, 'a recent count revealed [that] more than 1,200 [US] appellate cases were devoted to the question of what the word "shall” means', see Kimble, cited by Rosemarie Ostler, 'The Joys of Plain English' (2001) 30 Student Lawyer Law Review 35. See, generally, Christopher Williams, 'Fuzziness in Legal English: What Shall we Do with Shall' in Anne Wagner and Sophie Cacciaguidi-Fahy (eds), Legal Language and the Search for Clarity: Practice and Tools (Peter Lang 2006) 237ff; Nora Rotter Tillman and Seth Barrett Tillman, 'A Fragment on Shall and May' (2010) 50 American Journal of Legal History $453 \mathrm{ff}$.

12 Emphasis added.

13 John McMahon, 'Implementation of the United Nations Convention on Foreign Arbitral Awards in the United States' (1971) 2 Journal of Maritime Law and Commerce 753. Professor van den Berg's Hypothetical Draft Convention on the International Enforcement of Arbitration Agreements and Awards urges to amend the text of art II. For a different view, see Emmanuel Gaillard, 'The Urgency of Not Revising the New York Convention' Albert Jan van den Berg (ed), 50 Years of the New York Convention: ICCA International Arbitration Conference ICCA Congress Series (vol 14, Kluwer Law International 2009) 689-96.

14 Not least because judges 'are expected to identify workable options for the "management" of vague texts', see Divide Simone Giannoni, “Any dispute shall be settled by arbitration: A Study of Vagueness in International Model Arbitration Clauses' in Vijay Kumar Bhatia and others (eds), Vagueness in Normative Texts (Peter Lang 2005) 439.

15 For an explanation of the expressions 'null and void, inoperative or incapable of being performed', see Loukas A Mistelis and Julian D M Lew, 'Applicable Laws and Procedures in International Commercial Arbitration: Section C' (University of London 2005) 21-22; Julian D M Lew, Loukas A Mistelis, and Stefan Kröll, Comparative International Commercial Arbitration (Kluwer Law International 2003) 341-45; and Gary B Born, International Commercial Arbitration: Commentary and Materials (2nd edn, Kluwer Law International 2001) 160.

16 Albert Jan van den Berg, 'New York Convention of 1958: Annotated List of Topics' ( 29 September 2013) New York Arbitration Convention < www.newyorkconvention.org > accessed 18 February 2017.

17 The expression 'null and void' has been labelled as 'a lawyer's tautology - a needless string of words with the same or nearly the same meaning', Richard Wydick, 'Plain English for Lawyers' (1978) 66 California Law Review 734. However, they are likely to be similarly understood both in most civil and common law systems.

18 The comparison between the 2005 Convention on Choice of Court Agreements and the 1958 New York Convention is apposite because it is believed that the former 'may, in the long-term, facilitate the creation of a recognition and enforcement regime for court judgments as between the Contracting States, similar to that which exists in the arbitration context under the New York Convention'. See Linklaters, 'A User's Guide to the Hague Convention on Choice of Court Agreements'(Linklaters Dispute Resolution 2015) 4.. 
Convention has no choice-of-law rule, ${ }^{19}$ which, regrettably, has led to sterile disagreements over what the applicable law should be. ${ }^{20}$ Nonetheless, it can be said that, as the law stands, there is support for the postulate that the court's finding as to whether or not an international arbitration agreement is 'valid' under Article II.3 must inexorably be made in accordance with the law chosen by the parties. ${ }^{21}$

This line of thought is supported by Article V.1(a) of the New York Convention, ${ }^{22}$ which provides that:

Recognition and enforcement of the award may be refused, at the request of the party against whom it is invoked, only if that party furnishes to the competent authority where the recognition and enforcement is sought, proof that ... the agreement referred to in article II ... is not valid under the law to which the parties have subjected it. ${ }^{23}$

Although Article V.1(a) refers to cases in which recognition and enforcement of the 'award' may be refused, it is clear that, in the absence of an arbitral award or, put differently, at the pre-award stage, the criterion to be applied must be exactly the same. ${ }^{24}$ As a result, it can be argued that, once a request for recognition and enforcement of a given international arbitration agreement has been advanced before the court of a contracting state, any pronouncement as to whether it is either 'valid' or 'null and void' - by virtue of Article II.3 of the New York Convention-must also be made on the basis of 'the law to which the parties have subjected it'.

19 See Louise Ellen Teitz, 'The Hague Choice of Court Convention: Validating Party Autonomy and Providing an Alternative to Arbitration' (2005) 53 American Journal of Comparative Law 554. It is important to remember that choice-of-law rules 'tell courts and other adjudicators which sovereign's law to apply to which issues under which circumstances', in Caleb Nelson, 'State and Federal Models of the Interaction between Statutes and Unwritten Law' (2013) 80 The University of Chicago Law Review 666.

20 cf Matthew Cobb, 'Domestic Courts' Obligation to Refer Parties to Arbitration' (2001) 17 Arbitration International 316.

21 See van den Berg (n 16) 26-27. See also Leonard V Quigley, 'Accession by the United States to the United Nations Convention on the Recognition and Enforcement of Foreign Arbitral Awards' (1961) 70 Yale Law Journal 1064.

22 Note that arts V.2(a) and V.2(b) of the New York Convention also contain a choice-of-law rule.

23 Emphasis added.

24 cf Jean-François Poudret and Sébastien Besson, Comparative Law of International Arbitration (2nd edn, Sweet and Maxwell 2007) 299.

25 In principle, it would seem perverse for a court to apply a law other than the one chosen by the parties. Professor Yntema suggests that:

the exceptions to be made to the primary principle of party autonomy as respects contracts can simply be stated in terms of two sufficiently inclusive and flexible categories: first, cases in which in all substantial respects, except as to the law agreed upon by the parties, the contract is related to a single legal system and violates its mandatory requirements; second, cases in which there are well-founded objections on the ground of public policy

in Hessel Yntema, 'Contract and Conflict of Laws: “Autonomy” in Choice of Law in the United States' (1955) 1 New York Law Forum 66. Similarly, Professor Zhang explains that the principle of party autonomy has its limitations - 'the boundaries have evolved into three major areas: the public policy exception, the mandatory rule mandate, and the reasonable connection requirement', Mo Zhang, 'Party 
However, that is easier said than done. Most of the times, the parties are not careful enough to choose the law applicable to such an agreement. ${ }^{26}$ Further, it is likely that the law of the arbitration agreement 'will not necessarily be that [of] the main contract'. ${ }^{27}$ Because of the very nature of international arbitration, it is also probable that the 'governing law' will be a foreign one. ${ }^{28}$ Hence, it can be argued that, in entertaining the matter, there is a possibility that the courts may make an error in iudicando ${ }^{29}$ (hereinafter referred to as an 'error of judgment') and fail to refer the parties to arbitration.

Autonomy and Beyond: An International Perspective of Contractual Choice of Law' (2006) 20 Emory International Law Review 524. In practice, however, Professor William Park has noticed that the parties'

choice-of-law framework does not always lend itself to easy application in many international business problems where the scope of an agreement to arbitrate has been put at issue [eg] a company in Paris might contend that an American corporation should be bound by a contract, subject to French law, signed only by the corporation's Delaware subsidiary. The French company might invoke (rightly or wrongly) a theory of implied consent, under which an agreement to arbitrate would be found in the parent's negotiation of the subsidiary's obligations and performance of related contracts. In other words, the parent arguably agreed to arbitrate by virtue of its pattern of behavior

in William W Park, 'Rules and Standards in Private International Law' (2007) 73 Arbitration 443-44. See also William W Park, 'The Predictability Paradox: Arbitrators and Applicable Law', The Application of Substantive Law by International Arbitrators: Dossier XI of the ICC Institute of World Business Law (ICC Publication No 753E 2014) 68 (arguing that 'questions of applicable law often arise precisely because there is no obvious indication of which legal system (or systems) should govern the controverted question'). Professor Park's observations concerning the court's refusal to extend the agreement to arbitrate to non-signatories are no doubt compounded by the complexities that result from those cases in which such a determination has been made on the basis of foreign law.

26 See Hilary Heilbron, Dispute Resolution Guides: A Practical Guide to International Arbitration in London (Informa 2008) 22 (commenting that 'While it is common to find a law of the contract designated in the agreement, it is much rarer to see a specific provision for the law of the arbitration agreement'). Some leading commentators take the view that:

The parties need not make an express choice in relation to either the law governing the validity of the arbitration agreement or the law governing the procedure of the arbitration itself. This will often follow naturally from the circumstances; the law governing the arbitration agreement is generally that of the contract of which the arbitration clause is a part, and the law governing the conduct of the arbitration is usually that of the place or seat of arbitration

in Jan Paulsson, Nigel Rawding, and Lucy Reed, The Freshfields Guide to Arbitration Clauses in International Contracts (3rd edn, Kluwer Law International 2010) 17.

27 See Emmanuel Gaillard and John Savage (eds), Fouchard Gaillard Goldman on International Commercial Arbitration (Kluwer Law International 1999) 211. See also Carlo Croff, 'The Applicable Law in an International Commercial Arbitration: Is It Still a Conflict of Laws Problem?' (1982) 13 The International Lawyer 639 (holding that 'the validity of the arbitration agreement and the validity of the contract, are separate and therefore the law applicable to the former is not necessarily the same one applicable to the latter'). Note that 'The notion of one proper law to govern an agreement's material validity, scope, and interpretation has deep roots in English legal thinking', in William W Park, 'Explaining Arbitration Law' in Julio César Betancourt (ed), Defining Issues in International Arbitration: Celebrating 100 Years of the Chartered Institute of Arbitrators (OUP 2016) 16, fn 54.

28 It is said that 'One of the field's most striking and fascinating features is that, in any given dispute, the parties, their counsel, the arbitrators, and the applicable law are generally drawn from several different national jurisdictions', see John J Barceló III, 'Who Decides the Arbitrators' Jurisdiction? Separability and CompetenceCompetence in Transnational Perspective' (2003) 36 Vanderbilt Journal of Transnational Law 1116.

29 In Italian civil procedure, the notion of 'error of judgment' (error in iudicando) is one of the 'grounds upon which appellate judgments and non-appealable judgments of the ordinary courts may be reviewed', 
If the court fails to refer the parties to arbitration, it is widely accepted that the party against whom legal proceedings have been brought may subsequently claim damages against the party who took legal action for breach of the agreement to arbitrate, ${ }^{30}$ viz damages 'for the expenses incurred following breach of an arbitration agreement (the cost of defending and seeking to repel foreign proceedings brought in breach of the clause) ${ }^{31}$ Alternatively, it is submitted that, in certain cases, the party who has been deprived of the right to arbitrate may be entitled to make a claim for damages against the contracting state in which legal proceedings have been instituted for breach of Article II.3 of the New York Convention.

This article provides support for the proposition that when the court of a given contracting state does not comply with the 'obligation to refer the parties to arbitration', particularly, in those cases involving the application of foreign law, ${ }^{32}$ and in which an 'error of judgment' has been made, ${ }^{33}$ the contracting state infringes not only Article II.3 of the New York Convention, but also the requesting party's right to arbitrate the dispute. Thus it can be said that, for the reasons stated below, that state

see Mauro Cappelletti and Joseph M Perillo, Civil Procedure in Italy (Springer-Science+Business Media BV 1965) 276. In this article, however, this concept will be used lato sensu so as to explicate what happens when the court of a contracting state is asked to refer one of the parties to arbitration pursuant to art II.3 of the New York Convention and yet it decides not to do so as a result of an error of judgment.

30 For arguments in support of this proposition, see, for example, Zoe Schluter, 'Breach of an Arbitration Agreement: the Available Remedies' (24 March 2016) PLC Magazine < http://uk.practicallaw.com/> accessed 12 June 2016; Hakeem Seriki, Injunctive Relief and International Arbitration (Informa Law 2015) 135ff; Gabrielle Kaufmann-Kohler and Antonio Rigozzi, International Arbitration: Law and Practice in Switzerland (OUP 2015) 97; Albert Dinelli, 'The Limits on the Remedy of Damages for Breach of Jurisdiction Agreements: The Law of Contract Meets Private International Law' (2015) 38 Melbourne University Law Review 1023ff; David Joseph, Jurisdiction and Arbitration Agreements and their Enforcement (3rd edn, Sweet and Maxwell 2015) paras 14.05-14.12; Matthias Scherer, 'Damages as a Sanction for Commencing Court Proceedings in Breach of an Arbitration Agreement' (21 February 2014) Kluwer Arbitration Blog <www.kluwerarbitrationblog.com> accessed 20 January 2016; Simon Gabriel, 'Damages for Breach of Arbitration Agreements' in Manuel Arroyo (ed), Arbitration in Switzerland: The Practitioner's Guide (Kluwer Law International 2013) 1473-1481; Neil Andrews, The Three Paths of Justice: Court Proceedings, Arbitration, and Mediation in England (Springer 2012) 235; Sarah Garvey, 'West Tankers: Damages for Breach of Arbitration Agreement' (15 May 2012) Publications < www.allenovery. com > accessed 20 January 2016; Matthias Scherer, 'Court proceedings in Violation of an Arbitration Agreement: Arbitral Jurisdiction to Issue Anti-suit Injunction and Award Damages for Breach of the Arbitration Agreement' (2011) 14 International Arbitration Law Review 43; José Rosell, 'Arbitration Costs as Relief and/or Damages' (2011) 28 Journal of International Arbitration 123; Koji Takahashi, 'Damages for Breach of a Choice-of-court Agreement: Remaining Issues' (2009) 11 Yearbook of Private International Law 73-105; Adrian Briggs, Agreements on Jurisdiction and Choice of Law (OUP 2008) 499505; Justin Michaelson and Gordon Blanke, 'Anti-Suit Injunctions and the Recoverability of Legal Costs as Damages for Breach of an Arbitration Agreement' (2008) 74 Arbitration 12-27; Daniel Tan, 'Enforcing International Arbitration Agreements in Federal Courts: Rethinking the Court's Remedial Powers' (2007) 47 Virginia Journal of International Law 597ff; Daniel Tan, 'Damages for Breach of Forum Selection Clauses, Principled Remedies, and Control of International Civil Litigation' (2005) 40 Texas International Law Journal 623-61; Stuart Dutson, 'Breach of an Arbitration or Exclusive Jurisdiction Clause: The Legal Remedies if it Continues' (2000) 16 Arbitration International 89-100.

31 Neil Andrews, 'Courts Ensuring Compliance with Arbitration Clauses: The Position in English Law' (2014) 25 European Business Law Review 600.

32 Mainly because ' $[w]$ ith respect to matters of domestic law, the judge is assumed to know the law', see Allan Flanz, 'Judicial Notice' (1980) 18 Alberta Law Review 471. See (n 29) above. 
should be held liable in damages for the breach on the principle that where there is a right (ie 'the right to arbitrate') there is a remedy (ubi ius ibi remedium). ${ }^{34}$

It draws, primarily, upon the judgments relating to the case of National Navigation Co $v$ Endesa Generacion SA (both in the English High Court-the Commercial Court ${ }^{35}$-and on appeal to the Court of Appeal). ${ }^{36}$ Although these decisions do not provide guidance as to the circumstances in which state liability for breach of an international arbitration agreement is said to have arisen, they serve as the author's springboard for the premise that everyone who has been victim of a violation of the 'right to arbitrate', which can be more accurately designated as a 'New York Convention right' (under Article II.3 of the Convention), should have an enforceable right to compensation.

Since the New York Convention is an international treaty, this article will also delve into the area of public international law. ${ }^{37}$ Because all European Union (EU) Member States have ratified the New York Convention, ${ }^{38}$ and taking into account that EU legislation had far-reaching repercussions on the decision-making process that led to those judgments, ${ }^{39}$ it will also rely on certain principles of EU law that can be utilized so as to elucidate why it is juridically sound to allow for claims against Member States for their failure to comply with the obligation to refer the parties to arbitration. ${ }^{40}$

34 This maxim suggests that 'every legal right implies some form of remedy to rectify the consequences of a transgression of the right', Aaron Fellmeth and Maurice Horwitz, Guide to Latin in International Law (OUP 2011). It is interesting to note that 'English courts have long provided a private, legal remedy for statutory violations. In the 1703 case of Anonymous [87 Eng Rep (1378-1865) QB 791] an individual sued for damages, alleging a violation of a statute that contained no expressed remedy. The court reasoned that "where-ever a statute enacts anything, or prohibits anything, for the advantage of any person, that person shall have remedy to re-cover the advantage given him, or to have satisfaction for the injury done him contrary to law by the same statute; for it would be a fine thing to make a law by which one has a right, but no remedy ..."' (footnotes omitted), in Paul McMahon and Gerald Rodos, 'Judicial Implication of Private Causes of Action: Reappraisal and Retrenchment' (1976) 80 Dickinson Law Review 168. Although the court referred to 'statutory' violations, the same argument can be used, mutatis mutandis, in relation to treaty violations.

35 National Navigation Co v Endesa Generacion SA [2009] EWHC 196 (Comm), full judgment <http:// www.bailii.org/ew/cases/EWHC/Comm/2009/196.html> accessed 15 March 2016.

36 National Navigation Co v Endesa Generacion SA [2009] EWCA Civ 1397, full judgment <http://www.bai lii.org/ew/cases/EWCA/Civ/2009/1397.html> accessed 15 March 2016.

37 See Stephen Fietta and James Upcher, 'Public International Law, Investment Treaties and Commercial Arbitration: An Emerging System of Complementarity?' (2013) 29 Arbitration International 187 (holding that 'public international law has a substantial role to play in the protection of international commercial arbitration rights against interference by States'). The authors also address the question of state responsibility for the acts of judicial authorities.

38 EU Member States ratified the New York Convention as per below: Austria (1961), Belgium (1975), Bulgaria (1961), Croatia (1993), Republic of Cyprus (1980), Czech Republic (1993), Denmark (1972), Estonia (1993), Finland (1962), France (1959), Germany (1961), Greece (1962), Hungary (1962), Ireland (1981), Italy (1969), Latvia (1992), Lithuania (1995), Luxembourg (1983), Malta (2000), The Netherlands (1964), Poland (1961), Portugal (1994), Romania (1961), Slovakia (1993), Slovenia (1992), Spain (1977), Sweden (1972), and the UK (1975). See United Nations Treaty Collection (n 4).

39 Mainly because both Spain and the UK are members of the EU. At the time of writing, however, the UK has voted to leave the EU. See BBC, 'Brexit: What Happens Now?' BBC (29 June 2016) < http://www. bbc.co.uk/> accessed 28 June 2016. See also Nigel Rawding and Elizabeth Snodgrass, London Arbitration Following the Referendum Result_-Business as Usual? (Lexis PSL Dispute Resolution 2016) 1-3.

40 The topic appears to be quite timely, particularly, within the context of EU law. See, for example, Regina Valutyte, 'State Liability for the Infringement of the Obligation to Refer for a Preliminary Ruling under 
This article has been organized as follows: Section 2 provides a detailed summary of the facts and the law concerning the case of National Navigation Co $v$ Endesa Generacion SA. Section 3 deals with the effects of EU judgments on the validity of international arbitration agreements, particularly, within the context of (i) The Brussels Convention of 27 September 1968 ('the Brussels Convention'), (ii) Council Regulation (EC) 44/2001 of 22 December 2000 on Jurisdiction and the Recognition and Enforcement of Judgments in Civil and Commercial Matters ('the Brussels Regulation'), and (iii) Regulation (EU) 1215/2012 of the European Parliament and of the Council of 12 December 2012 on Jurisdiction and the Recognition and Enforcement of Judgments in Civil and Commercial Matters (Recast) ('the recast Brussels Regulation'). Section 4 looks at the obligation to refer the parties to arbitration pursuant to Article II.3 of the New York Convention and the principle of pacta sunt servanda. Section 5 focuses on the consequences of a failure to abide by Article II.3, especially, in the confines of international law. Section 6 goes on to explain the notion of state liability for judicial acts relating to the application of Article II.3. Section 7 sketches out the proposition that, in the above-mentioned case, Spain might have been liable for the breach of Article II.3. Section 8 sheds some light on the standard for determining wrongful failure to refer the parties to arbitration in accordance with EU law. Finally, Section 9 draws some concluding remarks.

\section{NATIONAL NAVIGATION CO V ENDESA GENERACION SA}

National Navigation Co (NNC) was an Egyptian company and the owner of Wadi Sudr (the Vessel). Endesa Generacion SA (EGS) was an electricity generating company domiciled in Spain. ${ }^{41}$ EGS entered into an individual contract to purchase a consignment of coal from Carboex (EGS's co-subsidiary). ${ }^{42}$ The coal was shipped aboard the Vessel $^{43}$ (as evidenced by a bill of lading) to be delivered at Ferrol (the contractual port of discharge under the bill of lading) in Spain. ${ }^{44}$ The Vessel sustained damage to her rudder and general average was declared soon thereafter. As a result, the coal was discharged at Carboneras in south-east Spain and not at the contractual port of discharge. ${ }^{45}$

the European Convention on Human Rights' (2012) 19 Jurisprudence 7-20 (stating that 'a state can be held liable for violations of fundamental rights guaranteed by the ECHR even when the violations are the consequence of implementation of EU law'). See also Arwel Davies, 'State Liability for Judicial Decisions in European Union and International Law' (2012) 61 International and Comparative Law Quarterly 585-611 (noting that 'State liability for judicial decisions in European Union (EU) and international law has its origin in the perception of the state as a single entity or unity [and that in] international law, the general position that state responsibility can be incurred for any breach applies in the same manner to all state branches').

41 National Navigation Co (n 35) [3].

42 ibid [4]-[5].

43 ibid [5]. Note that the Vessel was subject to various potentially relevant charters. First, NNC chartered the Vessel to China National Chartering Corporation ('Sinochart'), pursuant to a time charter ('the Head Charter'). The Head Charter was subject to English law and contained a London arbitration clause. Secondly, Sinochart sub-time chartered the Vessel to Morgan Stanley Capital Group Inc ('Morgan Stanley'), but neither party had a copy of this charterparty, and it was not in evidence. Thirdly, Morgan Stanley chartered the Vessel to Carboex under the terms of a voyage charter ('the Voyage Charter'). The Voyage Charter also contained a London arbitration clause, ibid [6]. 
EGS made an application to the Mercantile Court of Almería in Spain to arrest the Vessel and claim damages for late delivery under the bill of lading for discharging the cargo of coal at a port some way short of the contractual point of discharge. The application was heard ex parte and the order was granted. The order also required EGS to file its main claim within 30 days. ${ }^{46}$

NNC started an arbitration ${ }^{47}$ together with legal proceedings in the Commercial Court in London ${ }^{48}$ (without reference to any arbitration clause) ${ }^{49}$ claiming a declaration of non-liability. It also sought a stay from the Almería court on the grounds that there was an arbitration clause incorporated by reference to a charter party in the bill of lading $^{50}$ and, in the alternative, on the basis that the Commercial Court in London was first seised. ${ }^{51}$

EGS served its main claim, as required by the Almería Court. At the same time, NNC lodged submissions with the Almería Court challenging its jurisdiction. ${ }^{52}$ Eventually, the Almería Court rejected NNC's jurisdictional challenge and held that:

i. no arbitration clause was agreed or incorporated from any charter party into the Bill of Lading because the requirements for such agreement/incorporation under Spanish law ${ }^{53}$ had not been satisfied; in particular, Spanish law required the arbitration agreement and the choice of law agreement to be either expressly stated in the contract between the parties, or referenced in that contract and set out in 'other documents that directly bound the parties'; ${ }^{54}$

ii. in any event, by commencing the Commercial Court action NNC had waived the right to arbitrate the dispute under the alleged arbitration agreement and to challenge the jurisdiction of the Spanish court on the grounds that the dispute was referable to arbitration. ${ }^{55}$

46 ibid [11].

47 ibid [20].

48 ibid [2].

49 Mr Askins, NNC's solicitor, seems to have made various requests for copies of the Voyage Charter from Morgan Stanley, Carboex and Endesa, which had not resulted in any copy being provided, ibid [20]. As a result, NNC's counsel submitted that Mr Askins could not know for certain that there was indeed a London arbitration clause, ibid [54]. It was not until NNC's application for disclosure of the Voyage Charter was granted that EGS was ordered to disclose to NNC a copy of it, ibid [43].

50 National Navigation Co (n 36) [1]. For an analysis of this subject matter, see, generally, Melis Özdel, Bills of Lading Incorporating Charterparties (Hart Publishing 2015) 1-211. See also Melis Özdel, 'Enforcement of Arbitration Clauses in Bills of Lading: Where Are We Now?' (2016) 33 Journal of International Arbitration 151-169.

51 National Navigation Co (n 36) [1].

52 National Navigation Co (n 35) [15].

53 Emphasis added.

54 National Navigation Co (n 35) [33]. Interestingly, the Almería Court held that its decision would not be binding on the Commercial Court, and that the latter might well decide the incorporation and waiver/repudiation issues under English law in an opposite manner from that in which the Almería Court had decided such issues as a matter of Spanish law, ibid [121]. ibid [33]. 
However, it acceded to NNC's application that the Spanish proceedings should be stayed until the Commercial Court had decided whether it had jurisdiction $^{56}$ within the meaning of Article 27 of the Brussels Regulation. ${ }^{57}$ Both $\mathrm{EGS}^{58}$ and $\mathrm{NNC}^{59}$ appealed the decision of the Almería Court. Subsequently, the Almería Court delivered its judgment on NNC's appeal by way of reposición ${ }^{60}$ against that court's refusal to decline jurisdiction because of the agreement to arbitrate. It decided, amongst other things, that:

i. ... NNC had brought judicial proceedings (viz the Commercial Court Action) rather than arbitration proceedings in London, and thereby waived any arbitration agreement that might have existed between the parties. To this extent, the court confirmed its original decision.

ii. ... Since originally there had been only a request for the Spanish court to decline jurisdiction on the basis of Article 27 [of the Brussels Regulation], ie pre-existing court proceedings, NNC 'should not be allowed to request a refusal of jurisdiction on different grounds (submission to arbitration), rather than on those first put forward'. It held that there had been no request to the Almería Court to decline jurisdiction under Article 24 of the Regulation.

iii. ... As a matter of Spanish law-which was the correct law ${ }^{61}$ to apply to a procedural question whether judicial proceedings should be stayed-the arbitration clause was not incorporated. Moreover, English law had not been adequately asserted as the governing law of the dispute in the manner in which it should have been if it was to be considered by the court. ${ }^{62}$

As a result, NNC made various applications before the Commercial Court. ${ }^{63}$ The main thrust of the case was whether the Almería Court's judgments fell within the scope of the Brussels Regulation. NNC submitted that the English Court was bound

56 ibid [34].

57 art 27 of the said Regulation stipulated that:

1. Where proceedings involving the same cause of action and between the same parties are brought in the courts of different Member States, any court other than the court first seised shall of its own motion stay its proceedings until such time as the jurisdiction of the court first seised is established.

2. Where the jurisdiction of the court first seised is established, any court other than the court first seised shall decline jurisdiction in favour of that court.

58 EGS appealed the decision of the Almería Court to stay the Spanish proceedings pending the determination of the Commercial Court. Proceedings were stayed pending the Commercial Court's finding, National Navigation Co (n 35) [35].

59 NCC asked the Almería Court to review its decision refusing to reject jurisdiction because of the existence of an arbitration agreement, ibid [36].

60 A reposición can be defined as a procedural remedy aimed at obtaining an order declaring a decision made by a given court (the Almería's Court decision refusing to reject jurisdiction because of the alleged existence of the arbitration agreement) to be of no effect, so that the matter can be reviewed (or reconsidered) once again — by the same court-and a new judgment can be entered.

61 Emphasis added.

62 National Navigation Co (n 35) [46].

63 ibid [1]. 
to refuse recognition, ${ }^{64}$ whereas EGS alleged that the judgments clearly fell within the Regulation and, therefore, had to be recognized. ${ }^{65}$

It was common ground that if these judgments were not required to be recognized under the Brussels Regulation, EGS could not, in accordance with section 32(3) of the Civil Jurisdiction and Judgments Act $1982,{ }^{66}$ rely on ordinary principles of res iudicata and issue estoppel to contend that they were binding on the Commercial Court under the common law. ${ }^{67}$

The Commercial Court stated, inter alia, that: (i) in the light of the decision of the European Court of Justice (ECJ) in The Front Comor, ${ }^{68}$ the Almería Court's judgments in relation to the two relevant issues ${ }^{69}$ and the proceedings concerning NNC's challenge to the jurisdiction of the Spanish court leading up to those judgments fell within the Brussels Regulation; ${ }^{70}$ (ii) because Member States have their separate and respective obligations under the New York Convention, it cannot be assumed that one Member State will be in a position to accept-or should acceptthe decision of the court of another Member State in circumstances where the latter may well have applied 'its own law' to the question of the incorporation or validity of an arbitration clause ${ }^{71}$ and, therefore, concluded that the judgments of the Almería Court were not required to be recognized by reason of the arbitration exception con-

64 ibid [76].

65 ibid [80].

66 s 32 of the Civil Jurisdiction and Judgments Act 1982 provides that:

i. Subject to the following provisions of this section, a judgment given by a court of an overseas country in any proceedings shall not be recognized or enforced in the UK if:

a. the bringing of those proceedings in that court was contrary to an agreement under which the dispute in question was to be settled otherwise than by proceedings in the courts of that country; and

b. those proceedings were not brought in that court by, or with the agreement of, the person against whom the judgment was given; and

c. that person did not counter claim in the proceedings or otherwise submit to the jurisdiction of that court.

ii. Subsection (1) does not apply where the agreement referred to in para (a) of that subsection was illegal, void, or unenforceable or was incapable of being performed for reasons not attributable to the fault of the party bringing the proceedings in which the judgment was given.

iii. In determining whether a judgment given by a court of an overseas country should be recognised or enforced in the UK, a court in the UK shall not be bound by any decision of the overseas court relating to any of the matters mentioned in subsection (1) or (2).

iv. Nothing in subsection (1) shall affect the recognition or enforcement in the UK if:

a. a judgment which is required to be recognized or enforced there under [the 2005 Hague Convention], the 1968 Convention [or the Lugano Convention] [or the Regulation], [or the Maintenance Regulation] [or the 2007 Hague Convention];

b. a judgment to which p I of the Foreign Judgments (Reciprocal Enforcement) Act 1933 applies by virtue of s 4 of the Carriage of Goods by Road Act 1965, s 17(4) of the Nuclear Installations Act 1965, ... [regulation 8 of the Railways (Convention on International Carriage by Rail) Regulations 2005] ... or [s 177(4) of the Merchant Shipping Act 1995] (footnotes omitted).

67 National Navigation Co (n 35) [87].

68 Case C-185/07 Allianz SpA and Generali Assicurazioni Generali SpA $v$ West Tankers Inc.

69 See main text to nn (54-55) above.

70 National Navigation Co (n 35) [88].

71 ibid [97.v]. 
tained in Article $1(2)(\mathrm{d}) ;^{72}$ (iii) the bill of lading, on either basis, was subject to a London arbitration clause and English law; ${ }^{73}$ and (iv) NNC's declaration application ought to be granted. ${ }^{74}$ EGS appealed from the Commercial Court's judgment. The main issue was whether a judgment of a fellow Member State of the EU ruling against a stay of proceedings on the basis that an arbitration clause was not incorporated in the contract could be relied on as creating an issue estoppel to prevent the English Court deciding the point differently. ${ }^{75}$

The English Court of Appeal decided, amongst other things, that a Regulation judgment can give rise to an issue estoppel as much in arbitration proceedings excluded from the Brussels Regulation as in any other proceedings in an English court. ${ }^{76}$ It also stated that the UK's obligation under the New York Convention to give effect to arbitration agreements does not exempt an English court from its duty to enforce a decision of a court of a fellow Member State and co-signatory of the New York Convention that there was no arbitration clause. ${ }^{77}$ The appeal was allowed.

\section{THE EFFECTS OF EU JUDGMENTS ON THE VALIDITY OF INTERNATIONAL ARBITRATION AGREEMENTS}

The Brussels Convention on Jurisdiction and the Enforcement of Judgments in Civil and Commercial Matters of 27 September 1968 was superseded by Council Regulation (EC) 44/2001 of 22 December 2000 on Jurisdiction and the Recognition and Enforcement of Judgments in Civil and Commercial Matters. ${ }^{78}$ The latter was subsequently repealed by Regulation (EU) 1215/2012 of the European Parliament and of the Council of 12 December 2012 on Jurisdiction and the Recognition and Enforcement of Judgments in Civil and Commercial Matters (Recast). The recast Brussels Regulation contains a new set of 'rules on the jurisdiction of the [EU] courts and the ... recognition and enforcement of judgments in civil and commercial matters. ${ }^{79}$

Arbitration was always excluded not only from the scope of the Brussels Convention, but also from the scope of both Regulations. ${ }^{80}$ However, the so-called

72 ibid [97.vi].

73 ibid [112].

74 ibid [133].

75 National Navigation Co (n 36) [1].

76 ibid [59].

77 ibid [69]. The court referred to Allianz SpA and Generali Assicurazioni Generali SpA v West Tankers Inc [para 98], which states that ' $26 \ldots$ a preliminary issue concerning the applicability of an arbitration agreement, including in particular its validity, also comes within [the Brussels Regulation's] scope of application' [98].

78 See EUR-Lex Access to European Union Law, 'Jurisdiction, Recognition and Enforcement of Judgments in Civil and Commercial Matters (Brussels I)' <eur-lex.europa.eu> accessed 5 June 2016. For a commentary on the Brussels I Regulation, see Ulrich Magnus and Peter Mankowski, Brussels I Regulation (European Law Publishers 2007) 47. It is important to mention that the 1968 Brussels Convention paralleled the Lugano Convention on Jurisdiction and the Recognition and Enforcement of Judgments in Civil and Commercial Matters of 16 September 1988, which was later replaced by the new 2007 Lugano Convention. See, generally, Carl Baudenbacher, The Handbook of EEA Law (Springer 2016) 180.

79 European e-Justice Portal, 'Brussels I Regulation (recast)' <e-justice.europa.eu> accessed 5 June 2016.

80 See art 1.4 of the Brussels Convention; art 1.2(d) of the Brussels Regulation; and art 1.2(d) of the recast Brussels Regulation. For an authoritative account of the arbitration exclusion, see Hans van Houtte, 'Why Not Include Arbitration in the Brussels Jurisdiction Regulation?' (2005) 21 Arbitration International 510-12. 
'arbitration exclusion' or 'arbitration exception' and, especially, the question of whether or not judgments on the validity of international arbitration agreements are binding on the courts of Member States has (for all time) been the subject of considerable discussion. ${ }^{81}$ In what follows, an overview of the most salient remarks as regards these types of judgements is succinctly provided, particularly in relation to the applicability of the Convention and the aforementioned Regulations. ${ }^{82}$

\subsection{The Brussels Convention}

The Brussels Convention was an international treaty 'signed by the original Contracting States (Belgium, France, Germany, Italy, Luxembourg and the Netherlands)' on 27 September $1968 .{ }^{83}$ It introduced a new system whereby 'a judgment rendered in one Member State [was expected to be] automatically recognized and [enforced] in all other Member States, with some limited exceptions' ${ }^{84}$

Article 1.4 of the Convention stipulated that it should not apply to arbitration. ${ }^{85}$ Jenard's Report on the Convention on Jurisdiction and the Enforcement of Judgments in Civil and Commercial Matters also spelt out that it did 'not apply for the purpose of determining the jurisdiction of courts and tribunals in respect of litigation relating to arbitration, 86

It is evident that such broad statements would leave open a number of crucial points. Not surprisingly, when the UK took part in the discussion that preceded its accession to the Brussels Convention, the UK's delegation raised various issues concerning the effects of the arbitration exclusion. ${ }^{87}$

81 Judge Hascher tells us that the drafters of the 1961 European Convention on International Commercial Arbitration (the 1961 Geneva Convention) had initially contemplated the possibility to accord res judicata effect to the decisions of the judgment court on the validity or existence of an arbitration agreement ... However, it was finally decided that this matter should rather be dealt with in a Convention on the enforcement of awards or of foreign judgments than in a Convention on arbitration'. See Dominique Hascher, 'The European Convention on International Commercial Arbitration of 1961' in Albert Jan van den Berg (ed), Yearbook Commercial Arbitration (vol 36, Kluwer Law International 2011) 528.

82 At present, 'Member State court judgments on the existence and validity of an arbitration agreement do not circulate under the Regulation and therefore do not bind other courts', in Tony Cole and others, Legal Instruments and Practice of Arbitration in the EU (European Parliament 2014). Nonetheless, this section demonstrates that the matter has been subject to numerous debates. It might also explain why in National Navigation Co the English High Court's judgment differs markedly from that of the Court of Appeal.

83 A McClellan, 'The Convention of Brussels of September 27, 1968 on Jurisdiction and the Recognition and Enforcement of Judgments in Civil and Commercial Matters: Case Law of the National Courts and the Court of Justice of the European Communities' (1978) 15 Common Market Law Review 228.

84 Robert Reuland, 'The Recognition of Judgments in the European Community: The Twenty-Fifth Anniversary of the Brussels Convention' (1993) 14 Michigan Journal of International Law 562.

85 Note that the editors of the LCIA journal, ie Arbitration International, devoted a whole issue to the arbitration exception and the Brussels Convention. See vol 7, no 3, Arbitration International (1991) 179-298.

86 P Jenard, Report on the Convention on Jurisdiction and the Enforcement of Judgments in Civil and Commercial Matters (1968) No C 59/13. It is important to mention that in EU law these types of reports are not legally binding, Email from EUROPE DIRECT Contact Centre to author (22 July 2016).

87 The issues have been summarized as follows:

The United Kingdom supported a wide interpretation of the arbitration exception according to which it includes all disputes covered by arbitration clauses which are considered to be valid in a 
Towards the end of the 1970s, Professor Peter Schlosser's explanatory Report on the Association of the Kingdom of Denmark, Ireland, and the UK of Great Britain and Northern Ireland to the Convention on Jurisdiction and the Enforcement of Judgments in Civil and Commercial Matters and to the Protocol on its Interpretation by the Court of Justice, clarified some of the issues with respect to the applicability of the Brussels Convention in cases concerning judgments relating to the validity of agreements to arbitrate. Professor Schlosser's report stated, amongst other things, that:

Proceedings before national courts would ... be affected by [the Brussels Convention] only if they dealt with arbitration as a main issue and did not have to consider the validity of an arbitration agreement merely as a matter incidental to an examination of the competence of the court of origin to assume jurisdiction.

...

The 1968 Convention does not cover court proceedings which are ancillary to arbitration proceedings [thus] a judgment determining whether an arbitration agreement is valid or not, or because it is invalid, ordering the parties not to continue the arbitration proceedings, is not covered by the 1968 Convention. $^{88}$

In the 1980s, Professor Schlosser publicly recanted his position. In his opinion, 'great difficulties could arise if the Convention did not apply to court proceedings relating to arbitration and these difficulties would hardly be tolerated in the legal framework of the Community. ${ }^{89}$ For that reason, he concluded that the Brussels Convention 'applied to all court proceedings relating to arbitration'. 90

In the first half of the 1990s, Professor Bernard Audit analysed the relationship between national courts and arbitration, within the context of the Convention, and observed that it was seemingly inevitable that in some instances the validity or existence of an alleged arbitration agreement [would mean that] the courts of two Contracting States may take opposite views on that issue'. ${ }^{91}$

In the second half of the 1990s, Judge Dominic Hascher, who was at the time General Counsel and Deputy Secretary General of the International Chamber of Commerce, published an excellent article entitled 'Recognition and Enforcement of

\footnotetext{
Member State. The consequences would be that proceedings brought in breach of an arbitration agreement could neither trigger the lis pendens provision nor could judgments rendered in such proceedings be recognised and enforced under the Brussels Convention. The majority of Member States gave the exception a narrower meaning not excluding all proceedings brought in breach of an arbitration agreement from the scope of the Brussels Convention
}

in Julian D M Lew, Loukas A Mistelis, and Stefan Kröll (n 15) 500.

88 Peter Schlosser, Report on the Convention on the Association of the Kingdom of Denmark, Ireland and the United Kingdom of Great Britain and Northern Ireland to the Convention on Jurisdiction and the Enforcement of Judgments in Civil and Commercial Matters and to the Protocol on its Interpretation by the Court of Justice (1978) No C 59/91.

89 Peter Schlosser, 'The 1968 Brussels Convention and Arbitration' (1991) 7 Arbitration International 228.

90 ibid 242.

91 Bernard Audit, 'Arbitration and the Brussels Convention' (1993) 9 Arbitration International 25. 
Judgments on the Existence and Validity of an Arbitration Clause under the Brussels Convention'. 92

In his article, Judge Hascher adduces, inter alia, that:

[1] disputes relating to the existence or validity of an arbitration agreement as the main issue of the litigation, as well as judgments rendered in such proceedings, lie outside the sphere of the Brussels Convention. ${ }^{93}$ ...

[2] A court-issued declaratory judgment on the existence or the validity of an arbitration agreement should not ... be enforced under the Brussels Convention $^{94}$

[3] a judgment which has incidentally ruled on matters excluded from the scope of the subject matter of the Brussels Convention may be granted recognition under Title III of the Convention. It therefore follows that a judgment on the merits which contains a declaration on the ineffectiveness of an arbitration agreement falls within the scope of the provisions of the Convention. No control over the existence or validity of the arbitration agreement can moreover be exercised by the recognition or enforcement court under the Brussels Convention scheme. ${ }^{95}$

...

[4] it remains uncertain whether the various national courts will enforce or, instead, refuse to recognize foreign judgments regarding the existence or validity of an arbitration agreement. Indeed, there is no consensus as to the exact scope of the arbitration exclusion of the Brussels Convention. ${ }^{96}$ ...

[5] Article II(3) of the New York Convention, which unifies judicial standards for observing arbitration agreements, should be regarded as a truly jurisdictional rule which courts of the Contracting States should apply whenever the existence of an arbitration agreement is at issue before them.

92 Dominique Hascher, 'Recognition and Enforcement of Judgments on the Existence and Validity of an Arbitration Clause under the Brussels Convention' (1997) 13 Arbitration International 33-61. In this article, Judge Hascher refers to various cases, these include the 1991 case of Marc Rich and Co AG v Societa Italiana PA. In this case, the Court of Justice held, inter alia, that 'Article 1(4) of the Convention must be interpreted as meaning that the exclusion provided for therein extends to litigation pending before a national court concerning the appointment of an arbitrator, even if the existence or validity of an arbitration agreement is a preliminary issue in that litigation' I-3904. However, he also notes that in Marc Rich the crux of the matter was not 'whether a judgment on the substance of a dispute where there was an arbitration provision, or a judgment on the validity of an arbitration clause, was within or outside the Brussels Convention'. For a summary of the case, see Wolfram Krohn, 'Marc Rich \& Co. A.G. v. Societa Italiana Impianti P.A.' (1992) 86 American Journal of International Law 134-38.

93 Hascher (n 92) 39.

94 ibid 40.

95 ibid 53.

96 ibid 57.

97 ibid 60. 
A few years later, Jean-Paul Beraudo published an article concerning the arbitration exception. ${ }^{98}$ In this article, Beraudo made reference to Article II.3 of the New York Convention and, amongst other things, maintained that:

[1] All State Parties to the Brussels and/or the Lugano Convention, except Iceland, are Contracting States to the New York Convention. Consequently, in a vast majority of State Parties to the Conventions, if a defendant objects to the jurisdiction of the court on the ground that there is an arbitration agreement between the parties, the court should refer the parties to arbitration. The lack of jurisdiction of national courts in the presence of an arbitration agreement is based not on the Brussels Convention, but on the New York Convention. $^{99}$

...

[2] A judgment on commercial matters [for instance] undoubtedly falls within the scope of the Convention even if, before settling the substantive commercial dispute, the court has had to hear a dispute on the validity of an arbitration agreement. $^{100}$

...

[3] in cases in which the court before which recognition is sought does not share the negative opinion of the court of origin on the validity of an arbitration agreement, the correct basis for refusing recognition and enforcement is application of the specific convention. According to Article 57 of the Brussels Convention, Article II(3) of the New York Convention supersedes the Brussels Convention, which is to be regarded as a general instrument. ${ }^{101}$

At the same time, Dr Jacomijn van Haersolte-van Hof published an article ${ }^{102}$ contending that Beraudo's article failed to make a clear a distinction between 'a situation in which the validity of the arbitration agreement is the main issue (and presumably has been raised by the claimant), and a situation in which the validity is submitted as a defence, and constitutes a preliminary issue. ${ }^{103}$ Dr van Haersolte-van Hof adhered

Jean-Paul Beraudo, 'The Arbitration Exception of the Brussels and Lugano Conventions: Jurisdiction, Recognition and Enforcement of Judgments' (2001) 18 Journal of International Arbitration 13-26.

99 ibid 19.

100 ibid 21.

101 ibid 26. In this respect, Professor Hans van Houtte also pointed out that:

Article II ... not only explicitly obliges the courts to refer parties on the merits to arbitration whenever there is a valid arbitration clause; but also impliedly obliges the enforcing courts to refuse enforcement of a foreign court judgment whenever the enforcing judge considers the arbitration clause to be valid ... [T] he international obligation to apply the New York Convention is, for the enforcing court, a matter of "public policy" which excludes any enforcement of a court decision that would entail a breach of international treaty

in Hans van Houtte, 'May Court Judgments that Disregard Arbitration Clauses and Awards be Enforced under the Brussels and Lugano Conventions?' (1997) 13 Arbitration International 88.

102 Jacomijn van Haersolte-van Hof, 'The Arbitration Exception in the Brussels Convention: Further Comment' (2001) 18 Journal of International Arbitration 27-39. 
to the thesis that 'disputes relating to the existence or the validity of an arbitration agreement as the main issue of an arbitration fall outside the sphere of the [Brussels] Convention'. ${ }^{104}$ She goes on to suggest that it should not apply to those cases in which the validity of an agreement to arbitration is dealt with (as incidental matter $)^{105}$ and concludes by saying that 'courts may reach very different results on the evaluation of the validity of arbitration agreements, not least because the issue of the applicable law has not been finally settled by the New York Convention'. ${ }^{106}$

\subsection{The Brussels Regulation}

The Brussels Regulation ${ }^{107}$ (the law in force at the time the English Courts were asked to determine whether the Almería Court's judgments fell within the scope of the said Regulation) also laid down 'rules governing the jurisdiction of courts and the recognition and enforcement of judgments in civil and commercial matters in [EU] countries.' ${ }^{108}$

Since the Brussels Convention sparked numerous arguments about the scope of the arbitration exclusion, it became apparent that some clarification of the aforementioned exclusion was required. However, it can be said that the drafters of the Brussels Regulation fell short of the EU international arbitration community's expectations.

In 2003, some of the Brussels Regulation's implications, specifically in connection with the arbitration exclusion (including the question of whether or not a judgment on the existence, validity, and scope of an arbitration agreement must be recognized under the Regulation) were meticulously identified and systematically dissected by Clare Ambrose in one of her articles.

Ambrose's article provides a detailed analysis of the subject matter and a brief commentary on all the relevant authorities. Following an alternative line of reasoning, she argues that 'Another way of defining the boundary of the [arbitration exclusion is] to identify whether the subject matter of the claim is within the scope of the New York Convention'. ${ }^{109}$

Ambrose also explicates that:

The New York Convention requires a court to take a view on the existence, validity and scope of an arbitration agreement (under both Articles II and V). Accordingly, rulings on such matters should be outside the scope of the [Brussels Regulation]. ${ }^{110}$

107 In EU law, 'A “regulation” is a binding legislative act. It must be applied in its entirety across the EU', see European Union, 'Regulations, Directives and other acts' $<$ http://europa.eu/ $>$ accessed 6 June 2016.

108 EUR-Lex Access to European Union Law (n 78) accessed 6 June 2016.

109 Clare Ambrose, 'Arbitration and the Free Movement of Judgments' (2003) 19 Arbitration International 12.

110 ibid. 
Although the New York Convention is not designed for dealing with recognition of judgments and leaves potential for irreconcilable judgments on the existence of an arbitration agreement, it is probably preferable for such a ruling to be treated as outside the scope of the Regulation. The decision is clearly about arbitration and the matter is within the scope of the New York Convention. Such rulings should not be treated as Regulation judgments because this would mean that the ruling of one court on the issue of validity would require almost automatic recognition elsewhere in the EU. ${ }^{111}$

In September 2007, Professors Burkhard Hess, Thomas Pfeiffer, and Peter Schlosser published an in-depth report on the application of the Brussels Regulation within Member States (the Heidelberg Report). The Heidelberg Report identified several areas for improvement and, amongst other things, recommended that:

[the Brussels] Regulation should not address issues dealt with by the New York Convention. However, the prevalence of the New York Convention does not exclude supplemental and supporting provisions, especially provisions addressing the interfaces between the New York Convention and the Regulation. $^{112}$

In February 2009, the ECJ, as it was then called, held that:

if, because of the subject-matter of the dispute ... the nature of the rights to be protected in [the relevant] proceedings ... come within the scope of [the Brussels Regulation], a preliminary issue concerning the applicability of an arbitration agreement, including in particular its validity, also comes within its scope of application. ${ }^{113}$

Two months later, the European Commission published a report and a green paper on the application of the Brussels Regulation. The report expressly acknowledges that 'The rationale behind the [arbitration] exclusion is that the recognition and enforcement of arbitral agreements and awards is governed by the 1958 New York Convention, to which all Member States are parties.' ${ }^{, 14}$

111 ibid 13.

112 Burkhard Hess, Thomas Pfeiffer, and Peter Schlosser, 'Study JLS/C4/2005/03: Report on the Application of Regulation Brussels I in the Member States' (2007) 350.

113 In C-185/07 Allianz SpA $v$ West Tankers Inc. Some legal practitioners complained that:

This narrow interpretation of the arbitration exception gave rise to various problems for EUseated arbitrations. In particular, a counterparty could delay resolution of a dispute by starting a so-called "torpedo" action in another Member State on the merits, claiming that the arbitration agreement was invalid. The court of the seat would then be prevented from considering the validity of the arbitration agreement or referring the parties to arbitration (due to the rules on parallel proceedings which require any Member State court to stay its proceedings in favour of the court in which proceedings were commenced first)

in Herbert Smith Freehills, 'Handy Client Guide to Jurisdiction Under Recast Brussels Regulation' (2014) 30 . 
The Commission's report also highlights, inter alia, that:

[1] ... the interface between the [Brussels] Regulation and arbitration raises difficulties.

[2] there is no uniform allocation of jurisdiction in proceedings ancillary to or supportive of arbitration proceedings

...

[3] Arbitration falls outside the scope of the Regulation. The rationale behind the exclusion is that the recognition and enforcement of arbitral agreements and awards is governed by the 1958 New York Convention, to which all Member States are parties.

...

[4] the recognition and enforcement of judgments given by the courts in disregard of an arbitration clause is uncertain;

[5] the recognition and enforcement of judgments on the validity of an arbitration clause or setting aside an arbitral award is uncertain; ${ }^{115}$

Further, the Commission's green paper referred to the interface between the Brussels Regulation and arbitration. It stated that:

A uniform conflict rule concerning the validity of arbitration agreements, connecting, for instance, to the law of the State of the place of arbitration, might reduce the risk that the agreement is considered valid in one Member State and invalid in another. This may enhance, at Community level, the effectiveness of arbitration agreements compared to Article II(3) New York Convention. $^{116}$

On 3 September 2009, the UK responded to the European Commission's report and green paper on the operation of the Brussels Regulation. The UK's response was:

that the arbitration exclusion [should apply] to all aspects of the arbitral process. This should cover the following particular matters. First, if a court of a Member State is seised of an action that is the subject of an arbitration

114 Report from the Commission to the European Parliament, the Council and the European Economic and Social Committee on the application of Council Regulation (EC) No 44/2001 on Jurisdiction and the Recognition and Enforcement of Judgments in Civil and Commercial Matters (2009) 9 COM 174 final. ibid.

116 'Green Paper on the Review of Council Regulation (EC) No 44/2001 on Jurisdiction and the Recognition and Enforcement of Judgments in Civil and Commercial Matters' (2009) 9 COM 0175 final. A few months later, the European Economic and Social Committee advocated introducing a supra-national and uniform conflict rule with regard to the validity of arbitration agreements, which would refer to the law of the Member State in which arbitration takes place. This [was supposed to] be done while leaving the operation of the New York Convention untouched or at least as a basic starting point for further action'. See Opinion of the European Economic and Social Committee on the 'Green Paper on the review of Council Regulation (n 116) COM (2009) 175 final C 255/48. 
agreement, the matter should be resolved by the application of Article II of the New York Convention and that court's national law. The Regulation should not apply to the action. Secondly, the specific issue as to whether or not an arbitration agreement has in fact been concluded, is valid, operative, capable of being performed and of sufficient scope, should be excluded from the Regulation's ambit. Thirdly, all other court procedures ancillary to the arbitral process should be removed from the Regulation's coverage. And finally, judgments on the existence, validity, effect and scope of an arbitration agreement should also be excluded. ${ }^{117}$

Paradoxically, the UK's position contrasted starkly with the English Court of Appeal's stance in National Navigation Co $v$ Endesa Generacion SA. However, it has been said that 'The Court of Appeal's decision [was] unsurprising in the light of West Tankers and subsequent case law applying a narrow interpretation of the arbitration exception. ${ }^{, 18}$

\subsection{The Recast Brussels Regulation}

On 7 September 2010, the European Parliament prepared a resolution on the implementation and review of the Brussels Regulation and, amongst other things, considered that:

Article 1(2)(d) of the Regulation should make it clear that not only arbitration proceedings, but also judicial procedures ruling on the validity or extent of arbitral competence as a principal issue or as an incidental or preliminary question, are excluded from the scope of the Regulation; further [considered] that a paragraph should be added to Article 31 providing that a judgment shall not be recognised if, in giving its decision, the court in the Member State of origin has, in deciding a question relating to the validity or extent of an arbitration clause, disregarded a rule of the law of arbitration in the Member State in which enforcement is sought, unless the judgment of that Member State produces the same result as if the law of arbitration of the Member State in which enforcement is sought had been applied ... ${ }^{119}$

On 14 December 2010, the Commission put forward a considerably detailed proposal to recast the Brussels Regulation. One of the primary objectives of this proposal was to tackle the problems concerning the interface between the Regulation and arbitration. The Commission's proposal emphasized that:

117 Ministry of Justice, 'Review of the Brussels I Regulation (EC 44/2001): Comments from the United Kingdom’ (2009) para 37.

118 Stuart Dutson and Mark Howarth, 'National Navigation Co v Endesa Generacion SA (The Wadi Sudr); Dead Ahead? West Tankers Sails on in the Court of Appeal in The Wadi Sudr' (2010) 76 Arbitration 382.

119 European Parliament, 'Resolution of 7 September 2010 on the Implementation and Review of Council Regulation (EC) No 44/2001 on Jurisdiction and the Recognition and Enforcement of Judgments in Civil and Commercial Matters' (2010) para 10 (2009/2140(INI)). 
While the [Brussels] Regulation is overall considered to work successfully, the consultation of stakeholders and a number of legal and empirical studies commissioned by the Commission revealed a number of deficiencies in the current operation of the Regulation which should be remedied. ${ }^{120}$ ...

The proposal includes a specific rule on the relation between arbitration and court proceedings. It obliges a court seised of a dispute to stay proceedings if $[(\mathrm{a})]$ its jurisdiction is contested on the basis of an arbitration agreement and an arbitral tribunal has been seised of the case or [(b)] court proceedings relating to the arbitration agreement have been commenced in the Member State of the seat of the arbitration. ${ }^{121}$

Additionally, the Commission Staff published a working paper (impact assessment) calling for a revised Regulation. This working paper confirmed that the existing 'legal framework [did] not sufficiently protect the effectiveness of arbitration agreements in the EU'. ${ }^{122}$ As a result, 'an improvement of the [relationship] between court and arbitral proceedings' was envisaged. ${ }^{123}$

Professor Peter Arnt Nielsen narrates that 'During the recast negotiations, several proposals were discussed in addition to the one tabled by the Commission in the Proposal. One proposal examined was to abolish the exclusion of arbitration, whereas, at the other end of the spectrum, another proposal was a total exclusion of arbitration'. ${ }^{124}$

In December 2012, Regulation (EU) 1215/2012 of the European Parliament and of the Council of 12 December 2012 on Jurisdiction and the Recognition and Enforcement of Judgments in Civil and Commercial Matters (Recast) was eventually adopted, 'marking the end of a process lasting several years.' ${ }^{125}$ The recast Regulation is said to be less ambitious than the original proposal. ${ }^{126}$

However, unlike the Brussels Convention and the Brussels Regulation, the revised Regulation sought to partly decipher the scope of the arbitration exception through the incorporation of a new recital (recital 12) and a new provision (Article 73(2)),

European Commission, 'Proposal for a Regulation of the European Parliament and of the Council on Jurisdiction and the Recognition and Enforcement of Judgments in Civil and Commercial Matters (Recast)' (2010) 2 COM 748 final. ibid 8.

European Commission, 'Commission Staff Working Paper (impact assessment) accompanying document to the Proposal for a Regulation on Jurisdiction and the Recognition and Enforcement of Judgments in Civil and Commercial Matters (Recast)' (2010) 35 SEC1547 final . ibid 9.

See Peter Nielsen, ‘The New Brussels Regulation' (2013) 50 Common Market Law Review 507. Professor Nielsen also comments that 'One of the most difficult issues during the recast negotiations was the relationship between Brussels I and arbitration', in Peter Arnt Nielsen, 'The Recast Brussels I Regulation' (2014) 83 Nordic Journal of International Law 67. It is said that 'six alternative proposals were considered in the recasting process'. For a more detailed explanation, see Neil Dowers and Zheng Sophia Tang, 'Arbitration in EU Jurisdiction Regulation: Brussels I Recast and a New Proposal' (2015) 3 Groningen Journal of International Law 131. ibid 15. 
which provide further guidance on the recognition and enforcement of EU judgments on the validity of international arbitration agreements.

Recital 12, paragraph 2, of the recast Regulation provides that:

A ruling given by a court of a Member State as to whether or not an arbitration agreement is null and void, inoperative or incapable of being performed should not be subject to the rules of recognition and enforcement laid down in this Regulation, regardless of whether the court decided on this as a principal issue or as an incidental question. ${ }^{127}$

Article 73(2) seems to somewhat accord with some of the views taken by Hascher, Beraudo, and Ambrose, in the sense that it stipulates that the recast Regulation 'shall not affect the application of the 1958 New York Convention', which, as stated by recital 12, paragraph 3, takes precedence over the above-mentioned Regulation.

Consequently, it has been said that:

the outcome of the National Navigation case would not [have been] the same when applying paragraph 2 of recital 12, as the Spanish judgment deciding on the validity and existence of the arbitration agreement as a step on the way to the judgment on the merits would not be subject to the rules on recognition and enforcement of the [recast] Regulation. ${ }^{128}$

Nonetheless, some experts appear to have examined the matter in more detail and remain sceptical about the practical implications of the revised Regulation. Adam Johnson, Anna Pertoldi, Nick Peacock, and Hannah Ambrose of Herbert Smith Freehills, point out that 'there remain some circumstances for which the recast Brussels Regulation appears to provide no obvious solution'. ${ }^{129}$ For example:

$[\mathrm{P}]$ arty $\mathrm{A}$ issues proceedings in a member state court on the merits, arguing that a putative arbitration agreement is invalid. That court finds that there is no valid arbitration agreement and delivers a judgment on the merits. Meanwhile, party B has started arbitration proceedings seated in another member state, the tribunal has found that it has jurisdiction and is considering the merits of the dispute. Party A seeks to enforce the recast Brussels Regulation

It is important to bear in mind that, in EU law, 'The purpose of the recitals is to set out concise reasons for the chief provisions of the enacting terms, without reproducing or paraphrasing them. They shall not contain normative provisions or political exhortations', see Official Journal of the European Communities, Interinstitutional Agreement of 22 December 1998 on Common Guidelines for the Quality of Drafting of Community Legislation (1999/C 73/01) C 73/2.

128 Louise Hauberg Wilhelmsen, 'The Recast Brussels I Regulation and Arbitration: Revisited or Revised?' (2014) 30 Arbitration International 183. For a similar view, see Robert Merkin, Butler and Merkin's Reinsurance Law (Sweet and Maxwell 2016) ch D4, D-0811 (arguing that 'Recital 12 of Regulation $1215 / 2012 /$ EU appears to reverse the [National Navigation Co] ruling and indeed permits the English court to refuse to recognise a ruling from an EU court that an arbitration clause is null and void, inoperative or incapable of being performed').

129 Adam Johnson and others, The Recast Brussels Regulation: Implications for Commercial Parties (Thomson Reuters 2015) 6. 
judgment in a member state court (it may or may not be the court of the seat). There is no arbitral award that could be enforced in preference to the court judgment under paragraph 3 ... the language of Recital 12 will not provide any comfort to a party that wishes to enforce an award under the Convention in the member state court where the inconsistent judgment was made. In this case, there would be little chance that the court would reach any other decision than to uphold the court judgment, rule that the arbitration clause was invalid and refuse to enforce the award. ${ }^{130}$

Nevertheless, it can be argued that, in the example above, party B could have taken swift action to obtain an injunction from either the arbitral tribunal or an emergency arbitrator so as to restrain party A from continuing legal proceedings before the relevant EU court. ${ }^{131}$ In doing so, no judgment on the merits would have been validly rendered. ${ }^{132}$ This course of action is supported by Gazprom OAO $v$ Lietuvos Respublika. $^{133}$

ibid 7.

131 See, generally, Emmanuel Gaillard, 'Anti-suit Injunctions Issued by Arbitrators' in Albert Jan van den Berg (ed), International Arbitration 2006: Back to Basics? (Kluwer Law International 2008) 235-66. Indeed, "Whether or not arbitral tribunals may issue anti-suit injunctions depends on the relevant arbitration legislation, applicable arbitration rules and agreement of the parties, if any, as to such tribunal's power', Guido Carducci, 'Notes on the EUCJ's Ruling in Gazprom: West Tankers is Unaffected and Anti-suit Injunctions Issued by Arbitral Tribunals are Not Governed by EU Regulation 44/2001' (2016) 32 Arbitration International 121.

132 Even if the Member State court had reached a decision, research shows that, 'The average duration of a procedure of recognition of a judgment under the Brussels I Regulation (Regulation (EC) 44/2001 of 22 December 2000) [was] 6 months' and there is nothing to suggest that under the recast Brussel Regulation the length of these types of proceedings will be reduced. See Eric Dubois, Christel Schurrer, and Marco Velicogna, 'The Functioning of Judicial Systems and the Situation of the Economy in the European Union Member States: Compiled Report' (2013) 64.

133 In Gazprom, the Court of Justice of the European Union (CJEU) held that '[the Brussels Regulation] must be interpreted as not precluding a court of a Member State from recognising and enforcing, or from refusing to recognise and enforce, an arbitral award prohibiting a party from bringing certain claims before a court of that Member State,' Case C-536/13 'Gazprom' OAO v Lietuvos Respublika [45]. For a summary of the case, see Julio César Betancourt, 'Towards Another View of Anti-Suit Injunctions under EU Law (Part 2)' (2015) 4 The Resolver 9. See also Albert Jan van den Berg (ed), Yearbook Commercial Arbitration (vol 41, Kluwer Law International 2016) 1-33. Although the Gazprom decision was made under the Brussels Regulation, it has been said that the same conclusion can be arrived at under the recast Brussels Regulation, in Stephen Lacey, 'EU — The Gazprom Decision: CJEU Upholds the Ability of Arbitral Tribunals to Defend their Own Jurisdiction' (2015) Linklaters newsletter 4. For further guidance on recognition and enforcement of judgments and awards within the EU, see Trevor C Hartley, 'The Brussels I Regulation and Arbitration' (2014) 63 International and Comparative Law Quarterly 864-66. Note that in the Gazprom case, the 'CJEU did not consider one of the important questions, whether the prohibition of anti-suit injunction issued by [EU] courts as regards parallel proceedings within the EU should remain in place or lifted', in Jae Sundaram, 'Does the Judgment of the CJEU in Gazprom Bring About Clarity on the Grant of Anti-Suit Injunctions under The Brussels I Regulation?' (2015) 27 Denning Law Journal 322. According to AG Whathelet, however, 'anti-suit injunctions in support of ... arbitration are allowed by the Brussels I Regulation (recast)', see Opinion of Advocate General in Gazprom [137]. For some, litigants can rely on AG's opinion until the matter has been determined by the CJEU, Carlos González-Bueno and Laura Lozano, 'Anti-Suit Injunction: Where Does Gazprom Leave Us?' (2015) 24 Spain Arbitration Review 90. Nonetheless, it is important to remember that in Gazprom the CJEU stated that 'An injunction issued by a court of a Member State requiring a party to arbitration proceedings not to continue proceedings before a court of another Member State is 
It will be clear from the foregoing that the possibility of parallel proceedings ${ }^{134}$ and 'inconsistent decisions is a recognised consequence of excluding arbitration from the Recast Brussels Regulation and its predecessor. ${ }^{135}$ Nonetheless, it can be said that if there were any doubts as to whether EU member states could be lawfully exempted from their international obligation to refer the parties to arbitration (in accordance with Article II.3 of the New York Convention) so as to comply with the recast Regulation, they were certainly dispelled by Article 73(2).

\section{AS TO THE CONTRACTING STATES' OBLIGATION TO REFER THE PARTIES TO ARBITRATION AND THE PRINCIPLE OF 'PACTA SUNT SERVANDA'}

Article II.3 of the New York Convention can be described as a procedural norm. ${ }^{136}$ It is aimed, primarily, but not exclusively, at the courts of contracting states. ${ }^{137}$ This article usually comes into operation in those cases where A has taken legal action

contrary to the general principle which emerges from the case-law of the Court' [33]. At the time of writing, most commentators appear to be in favour of the proposition that anti-suit injunction granted by [EU] courts continue to be prohibited under the recast Brussels Regulation. See, for example, Neil Andrews, Arbitration and Contract Law: Common Law Perspectives (Springer 2016) 78 ('West Tankers Remains Applicable after the Brussels 1 Regulation (recast)'); Berk Demirkol, 'Ordering Cessation of Court Proceedings to Protect the Integrity of Arbitration Agreements under the Brussels I Regime' (2016) 65 International and Comparative Law Quarterly 401 ('it is unlikely that paragraph 2 of Recital 12 could be interpreted to reinstitute the power of domestic courts to take measures that interfere with the jurisdiction of other Member State courts under the Brussels I Recast in cases where these measures are related to the validity of an arbitration agreement'); Chukwudi Paschal Ojiegbe, 'From West Tankers to Gazprom: Anti-suit Injunctions, Arbitral Anti-suit Orders and the Brussels I Recast' (2015) 11 Journal of Private International Law 294 ('anti-suit injunctions remain impermissible notwithstanding the innovations under the Brussels I Recast'); Pietro Ortolani, 'Anti-suit Injunctions in Support of Arbitration under the Recast Brussels I Regulation' (2015) 6 MPILux Working Paper 9 ('anti-suit injunctions are incompatible with the Recast Regulation because they prevent Member State courts not only from deciding whether a valid arbitration agreement exists, but also from subsequently applying the rules on the allocation of jurisdiction set forth in the Regulation'). As a result, it is said that 'the powers available to state courts with regard to anti-suit injunctions relating to proceedings before courts of the EU Member States are fewer than those available to arbitral tribunals', Markus Burianski and Daniel Eckstein, 'Focus on the Practical Consequences of the ECJ's Gazprom Decision' (2015) White \& Case $<$ www.whitecase.com > accessed 19 July 2016. For a similar view, see Ewelina Kajkowska, 'Anti-suit Injunctions in Arbitral Awards: Enforcement in Europe' (2015) 74 Cambridge Law Journal 415 (concluding that 'in Europe, arbitrators have greater anti-suit powers than judges'). Lucy Greenwood of Norton Rose advises that 'Unless West Tankers is overruled, parties with EU-centric disputes should consider obtaining any anti-suit injunctions from an arbitral tribunal by means of an award enforceable under the New York Convention, rather than going to the courts of the seat of the arbitration for an anti-suit injunction in support of the arbitration', Lucy Greenwood, 'Anti-suit Injunctions in Europe' (2015) Norton Rose Fulbright <www.nortonrosefulbright.com> accessed 20 July 2016.

134 See, generally, Nadja Erk-Kubat, Parallel Proceedings in International Arbitration: A Comparative European Perspective (Kluwer Law International 2014) 1-352.

135 David St John Sutton, Judith Gill, and Matthew Gearing, Russell on Arbitration (24th edn, Sweet and Maxwell 2015) para 1-037.

136 In litigation, procedural norms are intended to regulate, amongst other things, the way in which jurisdictional function ought to be exercised. These norms have been designed to (i) control judges, parties, and even third-parties' behaviour in those cases where someone has taken legal action against another, (ii) set out a series of actions by way of mandatory and non-mandatory rules that prescribe what the accepted way of doing something within a given case is, and (iii) flesh out the burdens, rights, duties, and obligations that are necessary to produce the intended result, ie to enable the courts to do justice, $\mathrm{cf}$ Rafael Ortiz-Ortiz, Teoría General del Proceso (2nd edn, Frónesis 2004) 79. 
against $\mathrm{B}$ before the court of a contracting state and the latter asks the relevant court to refer the parties to arbitration on the basis that there is a valid international arbitration agreement, ${ }^{138}$ whereupon the court is expected to make such a referral, unless it concludes that the agreement is null and void, inoperative or incapable of being performed. $^{139}$

Given that the New York Convention acknowledges 'that arbitration agreements can, and will ordinarily, be separate agreements and that these agreements . . . will often be treated differently from, and subject to different rules of validity and different choice-of-law rules than, the parties' underlying contracts', ${ }^{140}$ it is plain to see why it makes sense to ascertain, $a b$ initio, what law governs the validity of the agreement to arbitrate. ${ }^{141}$ Having done so, the court should be able to effectively determine whether or not such an agreement is null and void.

In general, it can be said that the governing law is the one that 'the parties intended or may fairly be presumed to have intended the [agreement] to be governed'. ${ }^{142}$ Therefore, in deciding whether or not to refer the parties to arbitration within the meaning of Article II.3, the courts of contracting states are not entitled to apply 'any law' but the law chosen either 'expressly' or 'implicitly' by the parties. ${ }^{143}$

137 The language of art II.3 of the New York Convention appears to suggests, inter alia, that there is a 'right to request a referral to arbitration'. Such a right can be exercised by any individual, provided that the requirements described at page 27 are met. In the words of Professor Born, 'The essential core of an arbitration agreement is simple: it consists of nothing more than an obligation to resolve certain disputes with another party by "arbitration" and the right to demand that such disputes be resolved in this fashion' (emphasis added), in Gary B Born, International Arbitration: Law and Practice (Kluwer Law International 2012) 70. Thus, it can be argued that, in the international arena, such a right is enforceable not just as between all the relevant parties to the agreement to arbitrate, but also against the courts of contracting states.

138 The referral cannot lawfully be made by the court's own motion (motu proprio). See Loukas A Mistelis and Domenico di Pietro, 'New York Convention, Article II [Arbitration agreements]' in Loukas A Mistelis and Domenico di Pietro (ed), Concise International Arbitration (2nd edn, Kluwer Law International 2015) 11.

139 It has been said that 'Article II (3) does not imply an automatic and mandatory court referral to arbitration', see Guido Carducci, 'Validity of Arbitration Agreements, Court Referral to Arbitration and FAA s 206, Comity, Anti-suit Injunctions Worldwide and their Effects in the EU before and after the new EU Regulation 1215/2012' (2013) 24 American Review of International Arbitration 528. It is evident that the court's course of action may vary depending on whether or not the validity of the agreement has been previously challenged before an arbitral tribunal. See, generally, William W Park, 'Determining Arbitral Jurisdiction: Allocation of Tasks between Courts and Arbitrators' (1997) 8 American Review of International Arbitration 133-45; William W Park, 'Determining an Arbitrator's Jurisdiction: Timing and Finality in American Law' (2007) 8 Nevada Law Journal 135-68; Filip De Ly Chairman and Audley Sheppard (Rapporteur), 'ILA Final Report on Lis Pendens and Arbitration' (2009) 25 Arbitration International 20-31. See also John J Barceló III, 'Arbitrability Decisions Before, During, and After Arbitration' in Julio César Betancourt (ed), Defining Issues in International Arbitration: Celebrating 100 Years of the Chartered Institute of Arbitrators (OUP 2016) ch 7.

140 Gary B Born, International Commercial Arbitration (2nd edn, Kluwer Law International 2014) 356.

141 There is no doubt that the task of determining what the law applicable to an international arbitration agreement is can be fraught with difficulties. For a comprehensive analysis of this topic, see Gary B Born, 'The Law Governing International Arbitration Agreements: An International Perspective' (2014) 26 Singapore Academy of Law Journal 814-48.

142 cf Dicey, cited by JHC Morris and GC Cheshire, 'The Proper Law of a Contract in the Conflict of Laws' (1940) 56 Law Quarterly Review 320.

143 As to the law applicable to the arbitration agreement, especially, in those cases where the parties have not expressly agreed on the governing law, see Neil Kaplan and Olga Boltenko, 'The Dangers of 
In addition, Professor Albert Jan van den Berg explains that the referral must be made only if the rest of the requirements imposed by the New York Convention are met, namely:

i. the arbitration agreement must fall under the Convention;

ii. there must be a dispute;

iii. the dispute must have arisen in respect of a defined legal relationship and must come within the scope of the arbitration agreement;

iv. the arbitration agreement must be in writing; and

v. the subject matter must be capable of settlement by arbitration. ${ }^{144}$

Once the court of a contracting state has established that all the aforesaid requirements have been satisfied, it must comply with its obligation to refer the parties to arbitration. In Model Law countries, it is a matter for debate whether such a finding should be made after a 'full' or 'prima facie' review of the agreement on which the party against whom legal proceedings have been started intends to rely. ${ }^{145}$ Notwithstanding the method used, the UNCITRAL Guide on the Convention on the Recognition and Enforcement of Foreign Arbitral Awards (New York, 1958), states that:

In practice, the courts have fulfilled their obligation to refer the parties to arbitration in two different manners ... The first approach, endorsed by civil law jurisdictions, consists in declining jurisdiction in the presence of an arbitration agreement ... The second approach, endorsed by most common law jurisdictions, consists in staying judicial proceedings ... Both approaches [are said to be] consistent with the obligation of the courts of Contracting Parties to the Convention to refer the parties to arbitration. ${ }^{146}$

Neglect: Governing Law of Arbitration Agreement' in Julio César Betancourt (ed), Defining Issues in International Arbitration: Celebrating 100 Years of the Chartered Institute of Arbitrators (OUP 2016) ch 8; Renato Nazzini, 'The Law Governing the Arbitration Agreement: A Transnational Solution?' in Julio César Betancourt (ed), Defining Issues in International Arbitration: Celebrating 100 Years of the Chartered Institute of Arbitrators (OUP 2016) ch 9. In the absence of an express or implied choice of law, see, generally, Kurt Lipstein 'Characteristic Performance - A New Concept in the Conflict of Laws in Matters of Contract for the EEC' (1981) 3 Northwestern Journal of International Law and Business 402-14. See also Audley Sheppard, 'Chapter 12: Applicable Substantive Law' in Julian D M Lew and others (eds), Arbitration in England, with chapters on Scotland and Ireland (Kluwer Law International 2013) 233.

144 Albert Jan van den Berg, 'The New York Convention of 1958: An Overview' (Unpublished material) 10.

145 See Frédéric Bachand, 'Does Article 8 of the Model Law Call for Full or Prima Facie Review of the Arbitral Tribunal's Jurisdiction?' (2006) 22 Arbitration International 463. I concur with Professor Gaillard's thesis that 'the courts should limit ... their review to a prima facie determination that the agreement is not "null and void, inoperative or incapable of being performed" ', see Emmanuel Gaillard and Yas Banifatemi, 'Negative Effect of Competence-Competence: The Rule of Priority in Favour of the Arbitrators' in Emmanuel Gaillard and Domenico di Pietro (eds), Enforcement of Arbitration Agreements and International Arbitral Awards: The New York Convention in Practice (Cameron May 2008) 259.

146 United Nations, 'UNCITRAL Guide on the Convention on the Recognition and Enforcement of Foreign Arbitral Awards (New York, 1958): Note by the Secretariat, Addendum 2' (2014) 4-5. 
At first glance, the above referral procedure may appear quite straightforward. Nevertheless, in some cases, the task can be more complicated than it seems, especially, in those cases involving the application of foreign law, ${ }^{147}$ not least because 'national courts deal predominately with national cases for which national law and state interests are relevant.' ${ }^{148}$

As Professor Trimble has recently expounded 'Although courts do apply foreign law from time to time, the determination and application of foreign law can be difficult and may sometimes lead to errors that may cause results to be inconsistent with the foreign law and its application in the foreign country'. ${ }^{149}$

Hence, the various issues surrounding the application of foreign law cannot be understated. ${ }^{150}$ In the same way, problems such as '(1) the difficulty of access to the applicable foreign law ... (2) the added expense that the reference to foreign law entails; and (3) the tendency for experts to become partisans' are also a matter of considerable concern'. ${ }^{151}$

Even extrinsic issues, such as the judges' command of a foreign language and the reliance on-sometimes poorly-translated documents ${ }^{152}$ together with the everpresent elements of inaccuracy that the use of interpreters may potentially bring about are, perhaps, very likely to cause further problems.

147 Mainly because, 'Although courts are expected to know their own law, they cannot be expected to know the law of other countries', see Arthur Nussbaum, 'The Problem of Proving Foreign Law' (1941) 50 the Yale Law Journal 1018. While 'Courts are frequently required to deal with unfamiliar domestic statutes ... [it can be said that] instances of unknown or unfamiliar domestic law ... are the Exception [whereas] Total ignorance or imperfect knowledge of foreign law, on the other hand, is the rule', in Gregory Alexander, 'The Application and Avoidance of Foreign Law in the Law of Conflicts: Variations on a Theme of Alexander Nekam' (1975) 70 Northwestern University Law Review 603-04.

148 Julian D M Lew, Loukas A Mistelis, and Stefan Kröll (n 15) 439.

149 Marketa Trimble, 'The Marrakesh Puzzle' (2014) 45 International Review of Intellectual Property and Competition Law 787.

150 In essence, there are four issues. The first issue is said to be 'whether foreign law is considered as law, proven and interpreted as such, or whether the law of another jurisdiction is merely a matter of fact, to be applied only if and when parties to the case plead its application and prove its content and effectiveness', see Jacob Dolinger, 'Application, Proof, and Interpretation of Foreign Law: A Comparative Study in Private International Law' (1995) 12 Arizona Journal of International and Comparative Law 225. The distinction is important because 'The treatment of foreign law as a fact for purposes of pleading, proof, and appeal deprives the holdings on foreign law of one court from becoming rules which control the decisions of other courts under the rule of stare decisis. Nor does the determination of a foreign law issue in one case become res judicata in other cases involving the same question', see William Stern, 'Foreign Law in the Courts: Judicial Notice and Proof (1957) 45 California Law Review 28-29. The second issue, and perhaps the most fundamental one, is that of 'getting foreign law' right so as to correctly ascertain 'the foreign country's positive law as it actually is, not how that law ought to be (the lex ferenda)', in Marcus S Quintanilla and Christopher A Whytock, 'The New Multipolarity in Transnational Litigation: Foreign Courts, Foreign Judgments, and Foreign Law' (2012) 18 Southwestern Journal of International Law 43ff. The third issue is whether the application of foreign law should be applied upon the parties' request or ex officio, and the fourth issue is how to obtain the content of the foreign applicable law, see Stephen L Sass, 'Foreign Law in Civil Litigation: A Comparative Survey' (1968) 16 American Journal of Comparative Law 334.

151 John Henry Merryman, 'Foreign Law as a Problem' (1983) 19 Stanford Journal of International Law 155 .

152 As to the difficulties of legal translation, see Deborah Cao, 'Legal Translation' in Carol A Chapelle (ed) The Encyclopedia of Applied Linguistics (Blackwell Publishing Ltd 2013) 1-5. 
Within the EU, for example, the juridical framework for the application of foreign law has been heavily criticized by Professor Esplugues. In his General Report on the Application of Foreign Law by Judicial and Non-Judicial Authorities in Europe, he writes, amongst other things, that the current framework encourages the application of 'the lex fori by national authorities thus affecting the proper operation of the different EU Regulations on [choice-of-law rules] and impairing the achievement of the goal of uniformity that underlies them'. ${ }^{153}$

What is more, in EU law, choice-of-law rules pertaining to an international arbitration agreement have been excluded from the scope of the Regulation (EC) No 593/2008 of 17 June 2008 (Rome I) by virtue of Article 1.2(e). ${ }^{154}$ Furthermore, there is 'no international consensus on the choice of law rule applicable to an [international] arbitration agreement'. ${ }^{155}$ Thus, whenever the courts of EU Member States are asked to refer the parties to arbitration pursuant to Article II.3 of the New York Convention it is clear that the matter may be decided in many different ways. ${ }^{156}$

If the EU regulatory framework for the application of foreign law is tainted by several imperfections that may impinge on the operation of many EU Regulations, it stands to reason that some of the judgments espousing the enforcement of the abrogated Brussels Regulation ${ }^{157}$ and even the recast Brussels Regulation are likely to be the product of a real riddle that, to some extent, may stimulate forum shopping ${ }^{158}$ in EU Member States, which would end up defying one of the main aims of the New

153 Carlos Esplugues, 'General Report on the Application of Foreign Law by Judicial and Non-Judicial Authorities in Europe: (Project JLS/CJ/2007-1/03)’ 32011.

154 Professor Giuliano explains that 'The exclusion of arbitration agreements does not relate solely to the procedural aspects, but also to the formation, validity and effects of such agreements. Where the arbitration clause forms an integral part of a contract, the exclusion relates only to the clause itself and not to the contract as a whole', in Mario Giuliano, 'Report on the Convention on the law applicable to contractual obligations' (1980) No C 282/12. Even if they had been included in the Rome I Regulation, some would argue that the matter would have remained unresolved because art 1.3 'states that the rules of the Convention do not apply to evidence and procedure. Since the rules on pleading and proof of foreign law are clearly part of the law of evidence and procedure, it follows that [the Regulation would not have affected the rules of the contracting States on the pleading and proof of foreign law]', cf Trevor C Hartley, 'Pleading and Proof of Foreign Law: The Major European Systems Compared' (1996) 45 International and Comparative Law Quarterly 290.

155 Adrian Briggs and others (eds), Dicey, Morris \& Collins on the Conflict of Laws (vol 1, 15th edn, Sweet and Maxwell 2012) para 16-014.

156 cf Klaus Peter Berger, 'Re-examining the Arbitration Agreement: Applicable Law - Consensus or Confusion?' Albert Jan van den Berg (ed), International Arbitration 2006: Back to Basics? ICCA Congress Series (vol 13, Kluwer Law International 2007) 306 ('explaining that 'state courts ... must apply the conflict of laws rules of that lex fori [with the result that] different laws are applied to the same arbitration agreement in different jurisdictions').

157 It should be remembered that the Brussels Regulation was relied upon to prohibit the courts of EU member states from granting anti-suit injunctions to restrain foreign proceedings (brought in breach of international arbitration agreements) pending before the court of another contracting state, see Nigel Rawding and Constantine Partasides, 'The Future of Anti-suit Injunctions' (Freshfields Bruckhaus Deringer LLP 2009) 1-2.

158 The notion of forum shopping, in the sense described in this article, is related to the claimant's decision to file a claim in the court of a contracting state whose choice-of-law rules are likely to undermine the defendant's right to arbitrate the dispute, which is equivalent to a violation of art II.3 of the New York Convention. See, generally, Christopher A Whytock, 'The Evolving Forum Shopping System' (2011) 96 Cornell Law Review 481-534. 
York Convention, ${ }^{159}$ ie the recognition and enforcement of international arbitration agreements.

In light of the above observations, it can be said that when the courts of contracting states have to make a decision as to whether or not a given international arbitration agreement governed by foreign law is either 'valid' or 'null and void' the margin of judicial error is quite vast, with the result that (i) the law applied may not be the law applicable to the case in question (misapplication), (ii) the applicable law may be erroneously applied (misinterpretation), or (iii) the applicable law may not be applied at all (lack of application). ${ }^{160}$

When the court of a contracting state makes an error of this nature and, therefore, decides not to refer the parties to arbitration, ${ }^{161}$ it can be argued that the judge's error could be remedied on appeal. ${ }^{162}$ However, the language of Article II.3 of the New York Convention does not seem to favour a multi-tiered set of legal proceedings - from the court of first instance to the Supreme Court-aimed at recognizing and enforcing an international arbitration agreement. ${ }^{163}$ Nor does it seem to be compatible with the principle of effective judicial protection ${ }^{164}$ vis-à-vis the Convention.

The inevitable corollary of any of the above-mentioned scenarios (ie misapplication, misinterpretation, or lack of application) is that the judgment is 'valid', but it is not 'just'. ${ }^{165}$ If as a result of an error of judgment the party against whom legal proceedings have been initiated is prevented from settling the matter in arbitration (which is evidently contrary to Article II.3 of the Convention), one may conclude that the party's right to arbitrate the dispute has been thwarted by an 'unjust judgment' (sentencia injusta). ${ }^{166}$ These types of judgments contravene international law, particularly, the principle of pacta sunt servanda, which establishes that 'treaties which have legally come into existence and continue to be in force, must be kept'. ${ }^{167}$ It 'applies without exception to every treaty', ${ }^{168}$ including the New York Convention.

It is believed that 'a uniform conflict of laws rule can reduce forum shopping because the pointers in all courts will (theoretically) point to the same substantive law to govern a given dispute', William Wooward Jr, 'Contractual Choice of Law: Legislative Choice in an Era of Party Autonomy' (2001) 54 SMU Law Review 703.

160 cf Eduardo Couture, Fundamentos del Derecho Procesal Civil (3rd edn, Depalma 1981) 344-46.

161 Professor Guthrie writes 'judges are human. And like all humans, judges err. That judges err is acknowledged by our legal system. If there were no risk of judicial error, there would be no need for appellate courts', in Chris Guthrie, 'Misjudging' (2007) 7 Nevada Law Journal 420-21.

162 Mainly because a court of appeal is supposed to correct the lower court's errors. The problem is that, syllogistically speaking, appellate judges are also human and, therefore, they make mistakes too. See, generally, Anita Schnee, 'Logical Reasoning "Obviously" ' (1997) 3 The Journal of the Legal Writing Institute 107.

163 cf Roque Caivano, 'International Commercial Arbitration: 5.2 The Arbitration Agreement' (United Nations Conference on Trade and Development 2005) 6 (noting that 'It is the law governing the judicial proceeding that will determine whether an appeal can be made to the court's decision ... to retain its jurisdiction on the grounds that the arbitration agreement is null and void, inoperative or incapable of being performed').

164 As to the 'principle of effective judicial protection', particularly, within the context of EU law, see, for example, Koen Lenaerts, 'Effective Judicial Protection' (Unpublished material) < www.ec.europa.eu/> accessed 12 January 2016. 


\section{CONSEQUENCES OF A FAILURE TO ABIDE BY ARTICLE II.3 OF THE 1958 NEW YORK CONVENTION}

Article 26 of the 1969 Vienna Convention on the Law of Treaties ('the 1969 Vienna Convention') stipulates that 'Every treaty in force is binding upon the parties to it and must be performed in good faith' (pacta sunt servanda). Under international law, it is readily acknowledged that if a party to a treaty does not perform it, the party will ... be in breach of its international obligations to the other party or parties [and this would without a doubt] raise issues of State responsibility for the breach'. ${ }^{169}$

Professor Crawford, one of the world's leading experts on public international law, notes that 'State responsibility is a cardinal institution of international law. It results from the general legal personality of every State under international law, and from the fact that States are the principal bearers of international obligations' ${ }^{, 170} \mathrm{He}$ argues that almost 'any dispute concerning the rights and obligations of States can be presented as one concerning State responsibility'. ${ }^{171}$

The rules relating to state responsibility have been enshrined in the International Law Commission's Articles on Responsibility of States for Internationally Wrongful Acts (the ILC's Articles on State Responsibility). ${ }^{172}$ These articles 'are not in themselves legally binding [however they are] based on the long-standing rule of customary international law that every international wrongful act of a State entails the ... responsibility of that State'. ${ }^{173}$

Article 2 of the ILC's Articles on State Responsibility states that 'There is an internationally wrongful act of a State when conduct consisting of an action or omission: (a) Is attributable to the State under international law; and (b) Constitutes a breach of an international obligation of the State'. Notice that 'The conduct of any State organ shall be considered an act of that State under international law, whether the organ exercises legislative, executive, judicial or any other functions. ${ }^{174}$

Additionally, Article 12 of the ILC's Articles on State Responsibility provides, inter alia, that there is a 'breach of an international obligation ${ }^{\text {, }}{ }^{17}$ by a state when an act of that state is not in conformity with what is required of it by that obligation. ${ }^{176}$

Josef Kunz, 'The Problem of Revision in International Law' (1939) 33 The American Journal of International Law 42.

168 Mark Villiger, Commentary on the 1969 Vienna Convention on the Law of Treaties (Martinus Nijhoff Publishers 2009) 365.

169 Anthony Aust, 'Pacta Sunt Servanda', Max Planck Encyclopedia of Public International Law (February 2007) <http://opil.ouplaw.com> para 12 accessed 18 February 2017.

170 James Crawford, State Responsibility (Oxford Public International Law 2006) para 1.

171 ibid, para 67.

172 As for the work of the International Law Commission on state responsibility, see Philip Allott, 'State Responsibility and the Unmaking of International Law' (1988) 29 Harvard International Law Journal $2-13$.

173 Oliver Dörr and Kirsten Schmalenbach (eds), Vienna Convention on the Law of Treaties: A Commentary (Springer 2012) 1248.

174 art 4.1 of the ILC's Articles on State Responsibility.

175 The expression breach of an international obligation 'is long established and is used to cover both treaty and non-treaty obligations' in International Law Commission, 'Draft articles on Responsibility of States for Internationally Wrongful Acts, with commentaries' (United Nations, 2008) 35.

176 In international law, 'It is unanimously agreed that conduct of a State which is not in conformity with the conduct to be expected of it under a particular international obligation constitutes a breach of that 
Professor Shelton reminds us that the 'basic principles governing reparations following breach of an international obligation, ${ }^{177}$ were set forth by the Permanent Court of International Justice, as it was then called, in the Chorzów Factory case.

In this case, the court held, amongst other things, that:

The essential principle contained in the actual notion of an illegal act ... is that reparation must, as far as possible, wipe out all the consequences of the illegal act and re-establish the situation which would, in all probability, have existed if that act had not been committed. Restitution in kind, or, if this is not possible, payment of a sum corresponding to the value which a restitution in kind would bear; the award, if need be, of damages for loss sustained which would not be covered by restitution in kind or payment in place of it - such are the principles which should serve to determine the amount of compensation due for an act contrary to international law. ${ }^{178}$

Professor Villiger recounts that in 'the Middle Ages treaties specified the liabilities and procedures to be followed in case of breach of an international obligation'. ${ }^{179}$ However, the New York Convention is a relatively young treaty and, therefore, is silent on the point. As a result, it appears that both the 1969 Vienna Convention ${ }^{180}$ and the ILC's Articles on State Responsibility ${ }^{181}$ apply to those cases in which the breach of an obligation prescribed by the New York Convention is at stake.

Note that Article 27 of the 1969 Vienna Convention states that '[a] party may not invoke the provisions of its internal law as justification for its failure to perform a treaty.' Similarly, Article 32 of the ILC's Articles on State Responsibility provides, amongst other things that, 'The responsible State may not rely on the provisions of its internal law as justification for failure to comply with its obligations.' As a result, contracting states would not be entitled to invoke their internal law as justification for failure to comply with Article II.3 of the New York Convention. ${ }^{182}$

In view of the above, one may conclude that, if and when a breach of the New York Convention has been alleged, the International Court of Justice (ICJ) would have jurisdiction to decide whether or not a violation has occurred. This suggests that only 'States Members of the United Nations and other States which have

obligation', see Shabtain Rosenne (ed), The International Law Commission's Draft Articles on State Responsibility (Martinus Nijhoff Publishers 1991) 78.

177 Dinah Shelton, 'Righting Wrongs: Reparations in the Articles on State Responsibility' (2002) 96 American Journal of International Law 835.

178 Factory at Chorzów (Merits) Judgment No 13 [1928] Series A, 17 Publications of the Permanent Court of International Justice: Collection of Judgments 47.

179 Villiger (n 168) 898. A more recent example of these types of treaty provisions can be found in arts 13 and 14 of the 1992 United Nations Framework Convention on Climate Change, which has been ratified by 197 countries.

180 art 1 of the 1969 Vienna Convention on the Law of Treaties stipulates that it applies to 'treaties between States'.

181 cf Malgosia Fitzmaurice, 'International Responsibility and Liability' in Daniel Bodansky, Jutta Brunnée, and Ellen Hey (eds), The Oxford Handbook of International Environmental Law (OUP 2007) 1016.

182 James Crawford, The International Law Commission's Articles on State Responsibility: Introduction, Text and Commentaries (CUP 2002) 207-08. 
become parties to the Statute of the Court or which have accepted its jurisdiction ${ }^{, 183}$ may institute legal proceedings for breach of the Convention before the ICJ. ${ }^{184}$

This system, albeit commendable, is blatantly unsatisfactory when the victim of the transgression is not a state, ${ }^{185}$ mainly because in a run-of-the-mill international 'commercial' arbitration ${ }^{186}$ involving two or more private individuals, there is little likelihood that, whenever there is a breach of Article II.3 of the New York Convention, for example, the victim's contracting state will step into the breach and make a claim against the contracting state whose court has failed to refer the parties to arbitration.

At this juncture, however, it is clear that a failure to abide by Article II.3 of the New York Convention is tantamount to a breach of an international obligation. ${ }^{187}$ That individual against whom legal proceedings have been initiated may not be able to assert his 'right to arbitrate' under international law, but that is not to say that such a breach cannot be redressed by the national courts of the place in which these proceedings have been instituted.

The right to seek redress before the national courts of the New York Convention's contracting states for the infringement of the right to arbitrate a given dispute is, to be sure, duly justified. ${ }^{188}$ From the private individual's perspective, the breach that is said to give rise to 'state liability' ${ }^{189}$ arises perhaps not directly from the contravention of an international obligation, but from the violation of that

See International Court of Justice, How the Court Works < www.icj-cij.org > accessed 7 February 2016. art 34.1 of the Statute of the International Court of Justice provides that 'Only states may be parties in cases before the Court'.

It is clear that even contracting states are likely to be faced with the challenges of enforcing an ICJ judgment. For an analysis of this theme, see Mutlaq Majed AI-Qahtani, 'Enforcement of International Judicial Decisions of the International Court of Justice in Public International Law' ( $\mathrm{PhD}$ thesis, University of Glasgow 2003) 1-308. See also Veronika Fikfak, 'Domestic Courts' Enforcement of Decisions and Opinions of the International Court of Justice' (2014) 32 Legal Studies Research Paper Series 2-20.

the idea of state responsibility within the context of 'investment arbitration', see Kaj Hobér, 'State Responsibility and Investment Arbitration' (2008) 25 Journal of International Arbitration 545-68. See also Santiago Montt, State Liability in Investment Treaty Arbitration: Global Constitutional and Administrative Law in the BIT Generation (Hart Publishing 2009) 1-460.

cf William W Park, 'Convention Violations and Investment Claims' (2013) 29 Arbitration International 175.

It can be argued that such a right stems from the principles of 'equality' and 'parity'. As Professor Harlow explicates, 'Equality demands that state liability must somehow be assimilated into the ordinary civil law system administered by the "ordinary courts"; parity means the subjection of the state and its officials to the ordinary principles of civil liability', cf Carol Harlow, State Liability: Tort Law and Beyond (OUP 2004) 6-7.

In a recent publication, Ms Gerlich gives us a concise paraphrase of Schermers and Blokker's work explaining that "the notion of "responsibility" is used in relation to acts which involve breaches of international law, whilst the term "liability" has a broader meaning ... it refers ... to acts which are not unlawful under international law, but nevertheless have injurious consequences', in Olga Gerlich, 'Responsibility of International Organizations under International Law' 2 Folia Iuridica Wratislaviensis 12. As to the differences between the concepts of 'responsibility' and 'liability', see, for example, Julio Barboza, 'Differences between Responsibility and Liability' in Collected Courses of the Hague Academy of International Law: Documents of the fifty-second session (The Hague Academy of International Law 2016) 310-14; United Nations, Yearbook of the International Law Commission 2000 (vol II: part two, United Nations Publication 2006) 121. See also Sompong Sucharitkul, 'State Responsibility and International Liability under International Law' (1996) 18 Loyola of Los Angeles International and Comparative Law Review 821-39. 
individual's right to arbitrate the dispute, which has been embedded not only in an international arbitration agreement, but also in the very text of the Convention.

In effect, it is precisely because of the symbiotic relationship between international arbitration agreements and the New York Convention that the national courts of contracting states are compelled to refer the parties to arbitration. ${ }^{190}$ In other words, Article II.3 of the New York Convention obligates the national courts to safeguard the party against whom legal proceedings have been lodged in violation of a given international arbitration agreement. Hence, when the courts do not comply with their obligation to refer the parties to arbitration, the injured party should be able to invoke liability for breach of one of the most pivotal New York Convention rights.

Therefore, in those cases where the court of a contracting state has made an 'error of judgment' (in the sense described above) and consequently fails to refer the parties to arbitration, 'the obligation of full reparation ... [appears to be] an inseparable consequence of the breach'. ${ }^{191}$ Accordingly, it can be said that contracting states' failure to observe Article II.3 of the New York Convention amounts to an encroachment on the right to arbitrate that, as will be seen below, is bound to result in liability (under the national law of the country that refused to refer the parties to arbitration) for judicial acts relating to the recognition and enforcement of an international arbitration agreement.

\section{THE NOTION OF STATE LIABILITY FOR JUDICIAL ACTS RELATING TO THE APPLICATION OF ARTICLE II.3 OF THE NEW YORK CONVENTION}

When the court of a contracting state 'erroneously' decides not to refer the parties to an international arbitration agreement to arbitration, it can be argued that the court's decision is not only contrary to Article II.3 of the New York Convention (and thus contrary to international law within the meaning of Article 12 of the ILC's Articles on State Responsibility), ${ }^{192}$ but also potentially unjust ${ }^{193}$ and, therefore, likely to entail the liability of the respective contracting state (under national law).

By virtue of the doctrine of privity of contract, one may be forgiven for thinking that an international arbitration agreement cannot confer rights or impose obligations arising under it on any person other than the parties to it. However, in practice, it tends to transform into a truly multilateral contract that has far-reaching repercussions for a vast array of protagonists (or consequential obligors) that are expected to perform certain functions and fulfil various obligations as a result of the recognition and enforcement of this very agreement. Thus, a valid international arbitration agreement, albeit inherently binding on the parties concerned, exerts a ripple effect upon numerous individuals, institutions, entities, hundreds of national courts, and an equally large number of contracting states. cf Crawford (n 170) para 15.

192 Note that, in recent times, when international law claims are made before the national courts, 'Claims denying the legal character of international law, invoking either state sovereignty - the lack of sovereign on the international level — or the lack of centralized enforcement mechanisms, have generally failed', see Mattias Kumm, 'International Law in National Courts: The International Rule of Law and the Limits of the Internationalist Model' (2003) 44 Virginia Journal of International Law 20. Furthermore, it is important to remember that 'According to rules of international law ... neither a Constitutional mandate nor the enactment of a statute provides an excuse for a treaty violation', see William W Park and Alexander Yanos, 'Treaty Obligations and National Law' (2006) 58 Hastings Law Review 2.

193 In the 1930s, Professor Sunderland argued that 'there can be no relief from an unjust judgment, unless the injustice of that judgment was due to the erroneous ruling of the judge', Edson Sunderland, 'The Proper Function of an Appellate Court' (1930) 5 Indiana Law Journal 495. 
The contracting state's liability under national law is unlikely to result from a rather peculiar provision that specifically allows the party against whom legal proceedings have been initiated (in violation of a valid international arbitration agreement) to take legal action against the contracting state in those cases in which a violation of Article II.3 of the New York Convention has occurred, but rather from the notions of 'liability for judicial acts' or 'liability for judicial default'. ${ }^{194}$

Professor Crawford points out that 'The structure of the State and the functions of its organs are not, in general, governed by international law ... the State remains free to determine its internal structure and functions through its own law and practice. $^{, 195}$ In doing so, the internal law of each state will usually regulate the way in which certain functions - such as the executive, legislative, and judicial function - are supposed to be exercised.

From a constitutional point of view, it can be said that, in certain cases, the exercise of these functions may be considered as an act of the state (for the purposes of attribution), insofar as they are constitutionally vested in it and inseparably associated with the use of public power. Internal law will generally stipulate what are the circumstances under which the exercise of executive, legislative, judicial (or any other public function) does or does not entail liability. ${ }^{196}$

Acts of the state are 'subject to the rule of law' and, therefore, should not be immune from judicial scrutiny. ${ }^{197}$ As Lord Bingham once noted, the state 'accepts that it may not do, at home or abroad, all that it has the power to do but only that which laws binding upon it authorise it to do'. ${ }^{198}$ Thus, it is only right that when the state infringes the law and, in so doing, places 'a special burden upon some individual or

194 A distinction has been drawn between 'personal liability of the judge (personal judicial liability) and the liability of the State for the acts of the judiciary (state liability)', in Helen Toner, 'Thinking the Unthinkable? State Liability for Judicial Acts after Factortame (III)' (1997) 17 Yearbook of European Law 165-66. This article is concerned with the latter category, ie 'state liability'. Historically, common law countries maintained that 'a judge cannot be held responsible in damages for his judicial acts, and that the state enjoys a like immunity', see Peter Herzog, 'Liability of the State of New York for "Purely Governmental” Functions' (1959) 10 Syracuse Law Review 34. It is important to point out that the common law position concerning principle of state immunity was essentially based on two grounds, ie 'the king can do no wrong' and 'the sovereign cannot be sued without his consent', see Reginald Parker, 'The King Does No Wrong-Liability for Misadministration' (1952) 5 Vanderbilt Law Review 167, 168. However, these principles are no longer tenable. As one commentator notes, 'If sovereign States and their agencies and instrumentalities are to be accountable for their actions toward private parties, there must be mechanisms in place not only for adjudicating legal claims against them, but also for enforcing the arbitral awards and court judgments that arise from those proceedings,' in George Foster, 'Collecting from Sovereigns: The Current Legal Framework for Enforcing Arbitral Awards and Court Judgments against States and their Instrumentalities, and some Proposals for its Reform' (2008) 25 Arizona Journal of International and Comparative Law 666. Crawford (n 182) 92.

196 This is important because the state cannot possibly 'be sued in all cases and for all forms of relief, cf Note, 'Sovereign Immunity of the States: The Doctrine and Some of Its Recent Developments' (1956) 40 Minnesota Law Review 241.

197 cf Duguit, cited by J Roland Pennock, 'Law and Sovereignty' 31 The American Political Science Review 625. This is fully justified on the basis that courts are 'the guardians of the "rule of law" ', cf Nikolas Rajkovic, " "Global law" and Governmentality: Reconceptualizing the "Rule of Law" as rule "Through' Law” ' (2010) 18 European Journal of International Relations 38. 
class of men, the public funds should normally compensate for the damage suffered'. 199

The 'contention that acts ordered or performed by [the state] should be removed from judicial scrutiny has its roots in antiquated notions of sovereign immunity. ${ }^{200}$ In the modern world, however, it would be very difficult, if not anachronistic or even despotic, to withstand the thesis that the doctrine of sovereign immunity can be used so as to unjustly disregard the maxim that 'no one, not even the government is above the law. 201

The concept of state liability for judicial acts and the right to compensation has been eloquently articulated by Dr Helen Toner in one of her articles. Dr Toner reasons that:

the court system can inflict significant loss, both economic and of other kinds: for example, deprivation of liberty, confiscation of property, fines or other criminal or quasi-criminal sanctions, significant delay in vindicating legal rights, the economic loss of a failed damages claim that ought to have succeeded, or a prohibition on some profitable activity that might otherwise have been undertaken. It is certainly the case that some litigants will find themselves without any apparent way of recovering these losses. Thus, once it is accepted that the State should not be above the law and should, in the absence of other particular circumstances or policy factors, not be immune from liability to compensate for damage wrongfully done ... it is difficult to see how it could be argued that the court system should be excluded from [liability]... ${ }^{202}$

If we posit that no one, not even the government, is above the law and that in most, if not all, civilized governments, 'The function of the Court is [amongst other things] to apply the law correctly, ${ }^{, 203}$ it follows that instances of misapplication, misinterpretation, or lack of application of the law cannot be legitimately condoned by the state, especially, in those cases where the court's error involves the application of an international treaty and the entertainment of a 'foreign law element'.

Therefore, it is submitted that only an irresponsible state would abstain from allowing a claim for compensation concerning an error of judgment that unfairly resulted in the futility of an international arbitration agreement ${ }^{205}$ that, according to

Harold Laski, 'The Responsibility of the State in England: To Roscoe Pound' (1919) 32 Harvard Law Review 452. It has been argued that 'The real question is how the costs of potential state liability for money damages should be balanced against the benefits of holding state governments accountable', in Erwin Chemerinsky, 'Seeing the Emperor's Clothes: Recognizing the Reality of Constitutional Decision Making' (2006) 86 Boston University Law Review 1079. Law 927.

201 See Erwin Chemerinski, 'Against Sovereign Immunity' (2001) 53 Stanford Law Review 1202.

202 Toner (n 194) 169.

203 Frank Haymond, 'Public Relations between Courts and Law Enforcement Officers and the Public' (1948) 38 Journal of Criminal Law and Criminology 410.

204 For an analysis of the different approaches and methods employed by the EU Member States when dealing with foreign law, see Swiss Institute of Comparative Law, The Application of Foreign Law in Civil Matters in the EU Member States and its Perspectives for the Future (Lausanne 2011) 1-544. 
the law applicable to such an agreement, should have been recognized and enforced by the court seised of the case within the meaning of Article II.3 of the New York Convention. $^{206}$

\section{HYPOTHESIZING ABOUT THE CASE OF NNC V KINGDOM OF SPAIN}

In the confines of modern constitutionalism, ${ }^{207}$ it can be said that irresponsible states can be divided into two categories, ie (i) unlawfully irresponsible states, and (ii) lawfully irresponsible states. An unlawfully irresponsible state is the one whose legislation does expressly allow for legitimate claims against the state being made and yet, in practice, such a legislation is hardly ever enforced. Whereas a lawfully irresponsible state is the one whose legislation does not allow for legitimate claims against the state being made, notwithstanding the seriousness of the damage inflicted upon the victims.

Professor Meltzer of Harvard Law School says that:

The European Community (EC) and the United States have contrasting approaches to the place of member state liability to private parties as a remedy for the violation of the law of the union. The EC recognizes a general doctrine of member state liability in damages for violations of EC law, while American states generally possess sovereign immunity from private damage claims for violations of federal law. ${ }^{208}$

These contrasting approaches demonstrate that, in general, legislation can be either in favour or against the idea of state liability. Neither approach can be said to be better than the other, given that sovereign states are free to conduct their own affairs as they see fit. Hence, at a national level, everything seems to suggest that, in certain cases, ${ }^{209}$ the whole concept of state liability may be subject to the maxim dura lex sed $l e x,{ }^{210}$ irrespective of how draconian it may appear.

205 There appears to be some kind of coalescence between the violation of the right to arbitrate that derives from an international arbitration agreement and the court $s$ refusal to comply with its obligation to refer the parties to arbitration pursuant to art II.3 of the New York Convention.

206 Some of the arguments raised with respect to the concept of state responsibility for wrongful setting aside of an award can be equally identified with the concept of state liability for breach of an international arbitration agreement, see Nigel Blackaby and others (n 3) paras 10.93-.95. The theme of state responsibility vis-à-vis the enforcement of arbitral awards, particularly, within the area of investment arbitration, has been recently dealt with in Bernardo Sepúlveda-Amor and Merryl Lawry-White, 'State Responsibility and the Enforcement of Arbitral Awards' (2016) Arbitration International 1-27.

207 See, generally, David ButleRitchie, 'Confines of Modern Constitutionalism' (2005) 3 Pierce Law Review $1-32$.

208 Daniel Meltzer, 'Member State Liability in Europe and the United States' (2006) 4 International Journal of Constitutional Law 39.

209 In the 1890s, Freund explained that 'There are evidently cases where justice demands the adjudication of rights against the state, while the logic of the law apparently forbids it', see Ernst Freund, 'Private Claims Against the State' (1893) 8 Political Science Quarterly 638.

210 Counterintuitive as it may seem, 'rules of law may be unjust', in Edmond Cahn, 'Justice, Power and Law' (1946) 55 The Yale Law Journal 354. 
The Spanish legislator, for instance, appears to be very much in favour of the idea of state-and up to very recently even Spanish judges ${ }^{211}$ _liability. ${ }^{212}$ Spain is said to have 'chosen a broad, no-fault state liability regime [in which] [f] ault is formally only important at most to determine the amount of damages'. ${ }^{213}$

The concept of state liability for judicial acts, in particular, has been hallowed by Article 121 of the Spanish Constitution, which states that 'Damages caused by judicial errors $^{214}$ as well as those arising from irregularities in the administration of justice, shall be subject to compensation by the State, in accordance with the law, ${ }^{215}$

Although neither the Spanish Constitution nor the legislation has ever defined the concept of 'judicial error, ${ }^{216}$ José Almagro Nosete, a magistrate of the Spanish Supreme Court, tells us that it encompasses both excusable and inexcusable acts as well as errors of fact and errors of law. ${ }^{217}$ It must be the product of a judicial decision that is binding upon the victim and results in quantifiable damages, excluding those cases in which the victim has contributed to the damage by any wilful or negligent act. ${ }^{218}$

Professor Cobreros Mendazona explains that the concept of 'state liability for judicial error $^{219}$ was further elaborated by a singular piece of legislation, ie la Ley Orgánica del Poder Judicial, which provides for a two-tier mechanism ${ }^{20}$ whereby the claimant is expected to obtain a Supreme Court's declaration that an irredeemable judicial error has been made and, if successful, he would be entitled to make a compensation claim against the state by means of a petition to the Spanish Ministry of Justice. ${ }^{221}$

The Spanish Ministry of Justice is so transparent about it that it has even developed a how-to and jargon-free dedicated web page containing all the relevant information on how to make such a claim. It comprises a brief explanation of the procedure for dealing with these sorts of claims, the types of recoverable damages, a

211 See, for example, Juan Pedro Quintana Carretero and others, La Responsabilidad Personal del Juez (Aranzadi 2008) ch 3. See also Ley Orgánica 7/2015, de 21 de julio, por la que se modifica la Ley Orgánica 6/1985, de 1 de julio, del Poder Judicial, recital v, and art 296.

212 For a complete analysis of the subject matter, see Jesús Gonzáles Pérez, Responsabilidad Patrimonial de las Administraciones Públicas (4th edn, Civitas 2006) 1-734.

213 Giuseppe Dari-Mattiacci, Nuno Garoupa, and Fernando Gomez-Pomar, 'State Liability' (2010) 18 European Review of Private Law 784.

214 Emphasis added.

215 Agencia Estatal Boletín Oficial del Estado, The Spanish Constitution (1978) 35. It is worth mentioning that art 121 of the Spanish Constitution regulates two different scenarios, namely (i) state liability for judicial error, and (ii) state liability for abnormal functioning of the justice system. For an explanation of these two scenarios, see Jose Maria Reyes Monterreal, La Responsabilidad del Estado por Error y Anormal Funcionamiento de la Administración de Justicia (Colex 1987) 17-41.

216 For a complete explanation of the concept of judicial error, see Juan Pedro Quintana Carretero, $\mathrm{La}$ Responsabilidad Personal del Juez (Consejo General del Poder Judicial 2009) 473-92.

217 See Juan Antonio Moreno Martínes (coordinator), La Responsabilidad Civil y su Problemática Actual (Dykinson 2007) 18.

218 ibid 19.

219 As to the notion of state liability for judicial error, see, generally, Gabriel Doménech Pascual, 'El Error de la Responsabilidad Patrimonial del Estado por Error Judicial' 199 Revista de Administración Pública $182-87$.

220 See arts 291.1 and 293.2 Ley Orgánica 6/1985, de 1 de julio, del Poder Judicial.

221 Eduardo Cobreros Mendazona, La Responsabilidad del Estado derivada del Funcionamiento Anormal de la Administración de Justicia (Civitas 1998) 22. 
three-page claim form, all the relevant legislation, periods of limitation, and methods of service (including both personal and email delivery). ${ }^{222}$

In practice, however, the concept of judicial error seems to have a residual character and, therefore, can only be utilized in very exceptional circumstances. ${ }^{223}$ Some commentators have gone as far as to suggest that such a concept is surrounded with multifarious difficulties, lacunae, and normative ambiguities that arise from a rather confusing and even contradictory jurisprudential tradition that is far from inspired by the principle of reparation. ${ }^{224}$

At any rate, the Spanish Supreme Court has also emphasized on various occasions that not all possible equivocations can be conceptualized as a judicial error, for such a category is to be reserved for very special cases in which a judicial decision is seen to contain a 'crass', 'patent', 'indubitable', 'unanswerable', or 'flagrant' error that has resulted in a 'conclusion that is either factually or legally illogical, irrational, grotesque or absurd'. 225

Despite its intricacies, it has been said that Spain has one of the most advanced legislative systems in the area of state liability for judicial error. ${ }^{226}$ Further, not only does the notion of judicial error figure prominently in the Spanish legal literature, but it is also widely alluded to in the Supreme Court's case law. ${ }^{22}$ However, it is unclear whether a claim might be justified on the basis of an unjust decision that stems from the misapplication, misinterpretation, or lack of application of Spanish law. $^{228}$

Given the vagueness of the guidance provided by the Supreme Court, it is highly improbable that these types of claims will be easily-if ever-allowed, not only in those cases involving the application of national law, but also in those cases in which foreign law is supposed to be applied. Let us now take a closer look at those situations where an unjust decision arises from the misapplication, misinterpretation, or lack of application of foreign law. Some commentators write:

Ministerio de Justicia, 'Reclamación de responsabilidad patrimonial por el funcionamiento de la Administración de Justicia' < www.mjusticia.gob.es> accessed 22 June 2016.

223 Pablo Acosta Gallo, La Responsabilidad del Estado-Juez: Error Judicial y Funcionamiento Anormal de la Administración de Justicia (Montecorvo 2005) 159.

224 Hernández Martín cited by Acosta Gallo, ibid 169.

225 See STS de 3 de octubre de 2008, REJ 7/2007 (stating that 'no toda posible equivocación es susceptible de conceptuarse como error judicial, sino que esta calificación ha de reservarse a supuestos especiales cualificados en los que se advierta en la resolución judicial un error "craso", "patente", "indubitado", "incontestable", "flagrante", que haya provocado «conclusiones fácticas o jurídicas ilógicas, irracionales, esperpénticas o absurdas') Translated by the author.

226 Vicente Carlos Guzmán Fluja, 'La Extensión del Principio de la Responsabilidad del Estado a la Actividad de la Administración de Justicia' (1994) 3 Dereito 130-131.

227 See, for example, Antonio Rafael Hernández Olivencia, El Error Judicial en la Jurisprudencia del Tribunal Supremo (Trivium 1995) 1-241.

228 Professor Dworkin taught us that judges are fallible and that 'It is a matter of injustice when [they] make mistakes about legal rights, whether these mistakes are in favor of the plaintiff or defendant', Ronald Dworkin, 'Hard Cases' (1975) 88 Harvard Law Review 1108. In a similar manner, Professor Kaufmann-Kohler notes that 'courts, when making decisions on international commercial arbitration matters, may make mistakes', see Gabrielle Kaufmann-Kohler, 'Commercial Arbitration Before International Courts and Tribunals — Reviewing Abusive Conduct of Domestic Courts' (2013) 29 Arbitration International 173. 
Spain maintains a somewhat erratic solution as to the role played by the parties and the court in relation to the application of foreign law. Despite its factual character, foreign law does not need to be pleaded by the parties. In accordance with Article 12(6) [of the Spanish Civil Code] the court must implement Spanish choice-of-law rules on a mandatory basis to all these situations in which a foreign element is deemed to exist. Therefore it is for the court to establish whether foreign or domestic law should be applied to the dispute at stake. $^{229}$

The above assertion lends support to the proposition that, when NNC challenged the Spanish court's jurisdiction on the grounds that there was an arbitration clause incorporated by reference to a charter party in the Bill of Lading, the court should have sought to establish what the applicable law was, ${ }^{230}$ as opposed to having-perhaps unreasonably-applied Spanish law to the detriment of NNC. This appears to be contrary to Article II.3 of the New York Convention, since, in the case in question, everything seemed to indicate that the validity of the agreement to arbitrate should have been judged on the basis of English law, and not Spanish law. ${ }^{231}$

As a result, it can be argued that, in the absence of an express provision to the contrary, NNC should have been able to make a claim for judicial error (viz for the lack of application of foreign law) against Spain. In other words, had it not been for the Spanish court's error, ${ }^{232}$ the matter would have been dealt with by an arbitral tribunal. ${ }^{233}$ Hence, judicial acts relating to the recognition and enforcement of an international arbitration agreement governed by foreign law, whether in Spain or elsewhere, should entail liability so as to ensure that one of the main objectives of the New York Convention is effectively achieved.

229 Carlos Esplugues, José Luis Iglesias and Guillermo Palao (eds), Application of Foreign Law (Sellier European Law Publishers 2011) 31.

230 I am of the opinion that every time an individual makes a request for recognition and enforcement of an international arbitration agreement pursuant to art II.3 of the New York Convention, which is usually accompanied by either a jurisdictional challenge or an application for stay of proceedings, there is an implied duty upon the courts of contracting states to forthwith determine what the law applicable to the agreement to arbitrate is, so that they can subsequently decide whether or not it is valid.

231 However, such an inquiry does not seem to have taken place. The court simply held that Spanish law 'was the correct law to apply to a procedural question whether judicial proceedings should be stayed', but it did not mention anything with respect to the law applicable to the agreement to arbitrate, which is of vital importance so as so comply with art II.3 of the New York Convention. See main text to (n 61) above.

232 Indeed, it can be said that "what appears to be a conscious desire to thwart the international arbitral regime could actually be nothing more than a judicial misunderstanding of a particularly complex area of law', see S I Strong, 'Improving Judicial Performance in Matters Involving International Arbitration' in Julio César Betancourt (ed), Defining Issues in International Arbitration: Celebrating 100 Years of the Chartered Institute of Arbitrators (OUP 2016) 334. However, it is clear that ignorance of the law does not excuse (ignorantia iuris non excusat) and, accordingly, judicial misunderstanding of international arbitration law can be no valid defence in proceedings arising from its breach.

233 In a recent article, Professor Main identified two pervasive problems relating to cases involving the application of foreign law, ie 'Courts frequently dismiss cases that would otherwise require them to apply foreign law. In other instances, litigants may have their rights and responsibilities determined pursuant to the wrong law'. See Thomas Main, 'The Word Commons and Foreign Laws' (2013) 46 Cornell International Law Journal 221. 
Hard law without sanctions is anything but effective. ${ }^{234}$ These kinds of laws can be very difficult to distinguish from a mere recommendation. The New York Convention is an international treaty that, amongst other things, has created a right that is directly enforceable by individuals in the courts of contracting states, ${ }^{235}$ ie the right to arbitrate. When the courts have infringed such a right, individuals should be entitled to seek redress for the breach, and the notion of state liability for error of judgment could serve as the starting point for the resolution of these types of vicissitudes, particularly, in the commercial arena.

Within the EU, however, it can be posited-although not without fear of contradiction-that the New York Convention has been indirectly incorporated into EU law. ${ }^{236}$ As a result, it can be argued that in those cases in which the recognition and enforcement of a given international arbitration agreement has been undermined by a Regulation judgment, thereby affecting the application of Article II.3 of the Convention, such a judgment might be contrary to Article 73(2) of the recast Regulation $^{237}$ and, therefore, the injured party might be entitled to make a compensation claim against the relevant Member State for violation of EU law. ${ }^{238}$

234 To some extent, I align myself with 'Interest-based scholars [who] tend to conclude that international law that is not backed by sanctions [might not be] effective', Oona Hathaway, 'Between Power and Principle: An Integrated Theory of International Law' (2005) 75 The University of Chicago Law Review 491.

235 See, generally, David Sloss (ed), The Role of Domestic Courts in Treaty Enforcement: A Comparative Perspective (CUP 2009) 1-658.

236 cf Paul Beaumont and Lara Walker, 'Recognition and enforcement of judgments in civil and commercial matters in the Brussels I Recast and some lessons from it and the recent Hague Conventions for the Hague Judgments Project' (2015) 11 Journal of Private International Law 39 (arguing that 'the [recast Brussels Regulation] clarifies that in the event of a clash between the recognition and enforcement of a valid judgment from a Member State and a valid arbitration award under the New York Convention the latter should prevail').

237 See, European Commission, 'Communication from the Commission to the European Parliament, the Council, the European Central Bank, the European Economic and Social Committee and the Committee of the Regions - The 2016 EU Justice Scoreboard' (2016) 11 (holding that 'When applying EU law, national courts [must ensure] that the rights and obligations provided under EU law are enforced effectively').

238 See, generally, Klaus-Dieter Borchardt, The ABC of European Union Law (European Union 2010) 110-11. It has been acknowledged that:

the principle of liability on the part of a Member State for damage caused to individuals as a result of breaches of Community law for which the State is responsible is inherent in the system of the Treaty (Joined Cases C-6/90 and C-9/90 Francovich and Others [1991] ECR I-5357, paragraph 35; Brasserie du Pêcheur and Factortame...paragraph 31; Case C-392/93 British Telecommunications [1996] ECR I-1631, paragraph 38; Case C-5/94 Hedley Lomas [1996] ECR I-2553, paragraph 24; Joined Cases C-178/94, C-179/94, C-188/94, C-189/94 and C-190/94 Dillenkofer and Others [1996] ECR I-4845, paragraph 20, Case C-127/95 Norbrook Laboratories [1998] ECR I-1531, paragraph 106 and [(Case C-424/97 Haim [2000] ECR I-5123] paragraph 26)

in Case C-224/01 Gerhard Köbler v Republik Österreich [30]. Professor Tridimas is of the opinion that 'The recognition of a right to reparation for breach of Community law in Francovich, signalled the apotheosis of judicial intervention in the law of remedies and provided the most evocative illustration of the principle $u b i$ jus, ibi remedium', in Takis Tridimas, 'Liability for Breach of Community Law: Growing up and Mellowing down?' (2001) 38 Common Market Law Review 301. See also Ami Barav, 'State Liability in Damages for Breach of Community Law in the National Courts' (1996) 16 Yearbook 


\section{THE STANDARD FOR DETERMINING WRONGFUL FAILURE TO REFER THE PARTIES TO ARBITRATION}

In a comparative analysis of the concept of state liability for judicial default within the EU, Dr Scherr classifies Member States' approach into four categories, namely (i) total exclusion of state liability for judicial breaches under domestic law; (ii) restricted scope of state liability for judicial breaches according to the source and/or the nature of the judicial act causing the breach; (iii) restricted form of state liability under domestic law limited by the degree of fault in a judicial act; and (iv) procedural obstacles to a comprehensive recognition of the principle of state liability for judicial breaches. $^{239}$

This suggests that, under national law, not all Member States can be held liable for breach of Article II.3 of the New York Convention. This also suggests that, even in those Member States in which the concept of state liability for judicial default has been recognized, the assessment of state liability claims - in general — might be subject to various different standards. Such a diversity of standards, albeit undesirable, can be seen as an opportunity to take stock of the problems associated with the application of foreign law within the EU, particularly, in cases involving the recognition and enforcement of an international arbitration agreement.

It the absence of uniform standards, ${ }^{240}$ it is submitted that an individual's 'right to arbitrate' is so intertwined with the 'obligation to refer' that, procedurally speaking, the party against whom legal proceedings have been initiated should only be expected to show (i) that there is a valid international arbitration agreement, which under Article II.3 of the New York Convention requires certain conduct of the court in which legal proceedings have been brought (a treaty-based mandatory referral subject to limited exceptions), and, at the same time, (ii) that the conduct of the relevant court is other than that required of the treaty, so that a cause of action can be effectively stated. $^{241}$

This is best illustrated by means of an example-if party A takes legal action against party B (in the court of Member State X) in breach of an international

of European Law 87-128; Michael Haba, The Case of State Liability: 20 Years after Francovich (Springer 2015) ch 6 . In addition, it has been said that 'State liability for an infringement of Community law by a decision of a national court adjudicating at last instance can be incurred only in the exceptional case where the court has manifestly infringed the applicable law', in Gerhard Köbler [53]. See Pedro Cabral and Mariana Chaves, 'Member State Liability for Decisions of National Courts Adjudicating at Last Instance: CASE C-224/01, Gerhard Köbler v Republik Österreich [2003] ECR I-10239’ (2006) 13 Maastricht Journal of European and Comparative Law 109-26. At the same time, the European Commission has stated that "Where rights guaranteed in EU law have been violated, the national court must provide effective judicial protection to all', see European Commission, 'Effective Justice Systems and Rule of Law' (2016) <http://ec.europa.eu/> accessed 24 June 2016. See also, Kathrin Maria Scherr, 'Comparative Aspects of the Application of the Principle of State Liability for Judicial Breaches' (2012) 12 ERA Forum 565-88.

239 Kathrin Maria Scherr, 'The Principle of State Liability for Judicial Breaches: The case Gerhard Köbler v. Austria under European Community Law and from a Comparative National Law Perspective' (Doctoral thesis, European University Institute 2008) 1-458.

240 Curiously, judges have neither complained of the absence of guidance, nor made substantial efforts to fill the void, mainly because, as Professor Reese would put it, 'it is easier for [judges] to apply their own law than that of another state', Willis L M Reese, 'The Hague Case: An Opportunity Lost' (1981) 10 Hofstra Law Review 200. cf Silas Harris, 'What is a Cause of Action?' (1928) 6 California Law Review 475. 
arbitration agreement governed by French law (for the purposes of this example, let us assume that the parties had chosen London as the seat of arbitration), the court of Member State X is legally bound to apply foreign law, ie French law (the law chosen by the parties) $)^{242}$ to determine whether the agreement to arbitrate is valid within the meaning of Article II.3 of the New York Convention. In doing so, it may 'erroneously' conclude that, under French law, such an agreement is not valid and consequently fail to refer the parties to arbitration.

In accordance with Recital 12, paragraph 2, in conjunction with Article 73(2) of the recast Brussels Regulation, it is clear that the judgment rendered by the court of contracting state $\mathrm{X}$ is not subject to the rules of recognition and enforcement laid down in such Regulation. However, it would be illogical, if not preposterous, to conceive that the courts of contracting state $\mathrm{X}$ have 'the final word' on the validity of a French international arbitration agreement. Surely the recast Brussels Regulation is not a licence to disregard EU judgments relating to the proper application of the law of a given Member State, but rather a licence to protect the New York Convention. Therefore, it is submitted that, in the interest of justice, a subsequent declaratory French-or even an English ${ }^{243}$ _ judgment on the validity of such an agreement should be sufficient evidence to demonstrate that the court of contracting state $\mathrm{X}$ has made an error of judgment (ie wrongful failure to refer the parties to arbitration for the misinterpretation of foreign law), and the same can be said about the probative value of a declaratory award ${ }^{244}$ holding that the agreement to arbitrate was valid under French law. The onus lay on the party against whom legal proceedings have been initiated to prove that the agreement to arbitrate is valid, whether by means of a judgment or an international award.

\section{CONCLUSION}

It is said that the New York Convention has set 'forth a "pro-enforcement" ... regime [that] rests on the presumptive validity — formal and substantive — of [international] arbitration agreements. ${ }^{245}$ This iuris tantum-or rebuttable presumption - of validity, as noted above, 'can only be reversed on a limited number of grounds', ie null and void, inoperative or incapable of being performed. ${ }^{246}$

While some contracting states, such as England, ${ }^{247}$ France, ${ }^{248}$ Switzerland, ${ }^{249}$ and Germany, ${ }^{250}$ to name just a few, are well versed in international arbitration law-and

242 This is perfectly possible, given that 'Most legal systems contain rules of the conflict of laws which deal with the application of foreign law and several theories have sought to answer the question how courts come to follow the will of a foreign sovereign legislator', Friedl Weiss, 'Quot Homines Tot Sententiae or Universal Human Rights: A Propos Mcgovern v. the Attorney-General' (1983) 46 The Modern Law Review 392.

243 Pursuant to art V.1 (a) of the New York Convention. See, van den Berg (n 144) 11 (propounding that 'The alternative conflict rule, referring to the law of the country where the award was made, can be read as the law of the country where the award will be made in the context of the exception "null and void, inoperative or incapable of being performed" in Article II(3)').

244 See, generally, Stefan Leimgruber, 'Declaratory Relief in International Commercial Arbitration' (2014) 32 ASA Bulletin 467-89.

245 International Council for Commercial Arbitration, ICCA's Guide to the Interpretation of the 1958 New York Convention: A Handbook for Judges (ICCA 2011) 37. ibid. 
have more than a literal understanding of the text of the Convention-some have been known to use their own laws so as to circumvent some of the obligations that derive from this important treaty. ${ }^{251}$

Article II.3 of the New York Convention is said to be 'a fundamental rule without which the international arbitral system would not have developed as it did'. ${ }^{252}$ However, it is devoid of sanctions and, to some extent, the lack of sanctions leaves parties unprotected against the courts of contracting states' errors of judgment regarding the validity of a given international arbitration agreement. ${ }^{253}$

These types of errors are more likely to occur in those cases in which the application of foreign law is required. This is so because 'generally cases coming before the courts of a forum will be determined by that forum's own law'. ${ }^{254}$ Even assuming that the courts of a given forum will honour a stipulation of foreign law, it is by no means certain that they will be able to apply that law correctly. ${ }^{255}$

Thus, when the court of a contracting state is asked to refer the parties to arbitration (pursuant to Article II.3 of the New York Convention) and the agreement to arbitrate is, on the face of it, 'valid', it should simply refer the parties to arbitration. ${ }^{256}$ If there is any doubt about the agreement's validity, it should seek to establish what the law applicable to the arbitration agreement is. ${ }^{257}$

If the agreement is subject to that forum's own law, the court is perfectly suited to decide if the said agreement is valid. Otherwise, it should err on the side of caution and follow a responsible course of action that is truly compatible with the aim of the

247 See, generally, Julian D M Lew and others (n 143) 1-732.

248 See, generally, Guido Carducci, Arbitration in France: Law and Practice (OUP 2017) 1-550.

249 See, generally, Gabrielle Kaufmann-Kohler and Antonio Rigozzi (n 30) above 1-672.

250 See, generally, Karl-Heinz Böckstiegel, Stefan Kröll, and Patricia Nacimiento (eds), Arbitration in Germany: The Model Law in Practice (2nd edn, Kluwer Law International 2015) 1-1136.

251 Furthermore, it has been said that in some countries the lack of precedents dealing with the Convention, local corruption and bias, or administrative and judicial delay can mean that the Convention's provisions may not be faithfully observed', in Stuart Dutson, 'Breach of an Arbitration or Exclusive Jurisdiction Clause: The Legal Remedies if it Continues' (2000) 16 Arbitration International 94.

252 Gabrielle Kaufmann-Kohler, 'How to Handle Parallel Proceedings: A Practical Approach to Issues such as Competence-Competence and Anti-Suit Injunctions' (2008) 2 Dispute Resolution Journal 111.

253 cf Adriana Braghetta, 'The Framework of the International Arbitration System: the Challenge Derived from the Improper Conduct of Judicial Courts' Albert Jan van den Berg (ed), International Arbitration: The Coming of a New Age? ICCA Congress Series (vol 17, Kluwer Law International 2013) 431 (denouncing that 'Some judicial courts improperly accept jurisdiction to rule on the merits of the case and do not refer the parties to arbitration').

254 Kirsty Hood, 'Drawing Inspiration? Reconsidering the Procedural Treatment of Foreign Law' (2016) 2 Journal of Private International Law 181, 182.

255 cf James Lowe, 'Choice of Law Clauses in International Contracts: A Practical Approach' (1971) Harvard International Law Journal 5.

256 As Professor Park would put it, 'An arbitration would go forward only if a court has been prima facie satisfied of the validity and application of the arbitration clause (no forgery or gun at the head during signing), subject to more extensive review at the award stage', in William W Park, 'Arbitral Jurisdiction in the United States: Who Decides What?' (2008) 1 International Arbitration Law Review 49. But see also Professor Albert Jan van den Berg's observation, text to (n 144) above.

257 It is submitted that such a determination is a key step in the process of deciding whether or not an international arbitration agreement valid. 
Convention to avoid making an error of judgment. ${ }^{258}$ Let it suffice to say that it should not indiscriminately apply its own law.

One thing is certain - 'alien judgments ${ }^{, 259}$ as to the validity of an international arbitration agreement governed by foreign law cannot possibly be subject to a lower standard of validity than that applicable in the national courts of the forum in which that law is usually applied (the court of original jurisdiction). These judgments should be an accurate reflection of the court of original jurisdiction's decision on the validity of such an agreement; had it had to decide the matter.

It remains to be seen 'whether the international legal order will evolve to accord new mechanisms to promote respect for the New York Convention', as Professor Park once commented. ${ }^{260}$ In the meantime, it might make sense to examine the viability of the idea of state liability for judicial acts - as a temporary expedient - to deal with those cases in which the misapplication of Article II.3 of the Convention is purported to have befallen an individual's right to arbitrate.

258 There is no easy answer to the problem. Perhaps the contracting states should draw up an interpretative declaration with the aim of resolving the problems associated with the application of art II.3, especially, in those cases involving a foreign law issue. art It might also be a fertile ground for international (judicial) cooperation in commercial matters. In principle, I would be tempted to say that the courts may either stay the proceedings or decline decision making power in favour of the court of original jurisdiction.

259 An alien judgment, in the sense described in this article, may be defined as a judicial endeavour to ascertain whether or not an international arbitration agreement (subject to foreign law) is valid by means of the application of such a law.

260 William W Park, 'Respecting the New York Convention' (2007) 18 ICC International Court of Arbitration Bulletin 13. Professor Michael Evans reminds us that 'The Permanent Court of International Justice, in the Exchange of Greek and Turkish Populations case, stated that it was self-evident that a State which had assumed valid international obligations was bound to make such modifications in its legislation as were necessary to ensure their fulfilment', in Malcolm Evans, International Law (4th edn, OUP 2014) 414. Although this case refers to the implementation of human rights violations, it can be argued that all international treaties are equally binding and, therefore, it can be further argued that states are supposed to do what is necessary so as to enforce compliance with their respective obligations under the New York Convention. 